\title{
CYCLOMETALLATED PLATINUM(IV) COMPOUNDS AS PROMISING ANTITUMOUR AGENTS
}

\author{
Margarita Crespo
}

Departament de Química Inorgànica i Orgànica, Secció de Química Inorgànica, Universitat de Barcelona, Martí i Franquès 1-11, E-08028 Barcelona, Spain. E-mail: margarita.crespo@qui.ub.es; ORCID: 0000-0002-708.06-9751

\begin{abstract}
Since the discovery of the anticancer activity of cisplatin by Rosenberg, extensive research has been carried out in order to develop new and more efficient platinumcontaining drugs. In recent years, platinum(IV) compounds are appealing due to their inertness and high lipophilicity. On the other hand, interest in organometallic platinum compounds such as cyclometallated platinum(II) compounds is based on their stability and on the fact that the presence of a $\sigma(\mathrm{Pt}-\mathrm{C})$ bond increases the lability of the ligand in trans. In contrast, cyclometallated platinum(IV) compounds which combine the properties imparted by the presence of a platinum(IV) centre and a cyclometallated ligand have received little attention. The aim of this review is to present the results obtained so far for cyclometallated platinum(IV) compounds tested as antitumour agents. These compounds are prepared either by intramolecular oxidative addition from electron-rich platinum precursors and adequate ligands or by intermolecular oxidative addition to previously obtained cyclometallated platinum(II) compounds. Tridentate [C,N,N']
\end{abstract}


cyclometallated platinum(IV) compounds containing one, two or three carbon donor ligands exhibit a remarkable cytotoxicity, in most cases greater than that of cisplatin, against a panel of human cancer cell lines. In contrast, compounds containing a $[\mathrm{C}, \mathrm{N}]$ platinacycle are less active. For the most active tridentate [C,N,N'] platinum(IV) compounds studies of DNA interaction, topoisomerase I, II $\alpha$, and cathepsin B inhibition and ROS generation are presented.

Keywords: Cyclometallation; platinum(IV); N-donor ligands; antitumour agents 


\section{1.- INTRODUCTION}

Platinum compounds have had a tremendous impact in several areas of inorganic chemistry such as coordination and organometallic chemistry and also in the establishment of reaction mechanisms. The existence of cis and trans isomers of $\left[\mathrm{PtCl}_{2}\left(\mathrm{NH}_{3}\right)_{2}\right]$ led Werner to infer a square-planar geometry for platinum(II) compounds while the study of the mechanisms of substitution reactions and of the trans effect in square-planar complexes were mostly investigated with platinum compounds. Concerning the development of organometallic chemistry, the first compound containing an unsaturated hydrocarbon attached to a metal was $\mathrm{K}\left[\mathrm{PtCl}_{3}\left(\mathrm{C}_{2} \mathrm{H}_{4}\right)\right] \cdot \mathrm{H}_{2} \mathrm{O}$ known as Zeise's salt, and $\sigma$-bonded compounds containing a trimethylplatinum(IV) group described by Pope and Peachey in 1907 are also historically significant [1]. Moreover, since the work from Shilov in the early 1970s, platinum has played an important role in the study of $\mathrm{C}-\mathrm{H}$ bond activation chemistry [2]. Finally, there is no doubt about the tremendous impact in the bioinorganic chemistry area of the discovery of the anticancer activity of cisplatin by Rosenberg [3] which was followed by an extensive research focused on the development of platinum compounds as potential therapeutics [4-8].

In spite of the variety of platinum compounds that have been studied in relation to their potential properties as anticancer agents, cyclometallated platinum(IV) compounds have received very little attention. In this review, we will present the results obtained so far for this type of compounds. In order to have a better understanding of the potential of cyclometallated platinum(IV) compounds as antitumor drugs, we will first analyse briefly the features of platinum (IV) versus platinum(II) (section 2) and of organometallic complexes, in particular those of platinum, studied as antitumor drugs (section 3) to 
finally focus on the research concerning cyclometallated platinum(IV) compounds as potential antitumor agents carried out in our group (section 4).

\section{2.- PLATINUM(IV) VERSUS PLATINUM(II) ANTICANCER DRUGS}

Since the discovery of the anticancer activity of cisplatin by Rosenberg [3], extensive research has been carried out in order to develop new and more efficient metal-containing drugs. The mechanism of action of cisplatin involves substitution of chlorido ligands for water molecules upon tumour cell entry, which is followed by binding to DNA nucleobases and tumour cell apoptosis or programmed cell death [5]. Currently, there are three platinum-based anticancer drugs used world-wide: cisplatin, carboplatin and oxaliplatin, while three more platinum(II) compounds have been approved for use in humans: nedaplatin, lobaplatin and heptaplatin (see figure 1). All the clinically used drugs are neutral square-planar platinum(II) compounds containing two mutually cis non-labile ligands (either two monodentate ammine or a bidentate diamine) and two labile or semi labile ligands mutually cis (two chlorido ligands or a chelate $\mathrm{O}, \mathrm{O}$ ligand) and this arrangement allows for a cytotoxic effect analogous to that of cisplatin [5, 9-11]. Recently, many efforts are dedicated to investigate "non classical platinum complexes" that may operate through distinct mechanisms such as trans-platinum(II) compounds, in which the leaving ligands are mutually trans [12], monofunctional platinum(II) compounds with only one labile ligand [13], platinum(II) compounds that act as metallointercalators in double strand DNA [14], or polynuclear platinum compounds $[15,16]$. 
<smiles>N[Pb](N)(N)Cl</smiles>

cisplatin<smiles></smiles>

nedaplatin<smiles>N[P+](N)(N)OC(=O)C12CCC1CO2</smiles>

carboplatin<smiles>CC(C)C1OC(CCC2COC(=O)CC2CCC(=O)O)[P+](N)(N)O1</smiles>

heptaplatin<smiles>O=C1O[Pb]2(N[C@@H]3CCCC[C@H]3N2)OC1=O</smiles>

oxaliplatin<smiles>CC1O[Pb](N)(N)OC1=O</smiles>

lobaplatin

Fig. 1.- The six platinum anticancer drugs approved for anticancer treatment in humans (cisplatin, carboplatin and oxaliplatin are used worldwide, nedaplatin, heptaplatin and lobaplatin are approved in Japan, Korea and China, respectively). Leaving ligands are indicated in red.

Platinum(IV) complexes were already investigated by Rosenberg but since they were less effective than cisplatin they were not studied in depth. In recent years, renewed interest in platinum(IV) compounds as new anticancer agents is based on the idea that they are capable of overcoming some of the problems associated with the platinum(II) drugs such as severe side effects and acquired resistance [5, 9-11, 17-19]. Platinum(IV) complexes have an octahedral geometry and are considered inert towards substitution reactions due to their low spin $\mathrm{t}_{2 \mathrm{~g}}{ }^{6}$ configuration. The idea underlying the design of platinum(IV) anti-tumour agents is that these compounds will be stable outside the cell, and will be activated by two-electron reduction only inside the cancer cell. Intracellular reduction can be produced in the hypoxic environments of cancer cells, which contain a high concentration of reducing agents, leading to the cytotoxic square-planar platinum(II) parent compound while the two axial ligands come off (See figure 2). 
<smiles></smiles>

PRODRUG activation by reduction

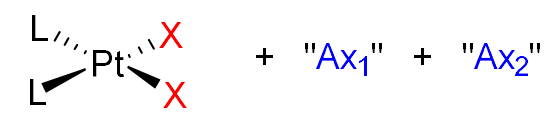

DRUG

Fig. 2.- Reduction of platinum(IV) prodrugs

The reduction of the platinum(IV) compounds is a relevant step [20-21], since if the reduction takes place before the prodrug reaches the tumour or, on the contrary, if the compound is resistant to reduction inside the cancer cell, the compound is probably inactive. Information on the ease of reduction of platinum(IV) to platinum(II) can be obtained by cyclic voltammetry and the reduction potential depends primarily on the nature of the axial ligands. It was observed that the reduction occurs more readily when the axial ligands are chlorido than when they are carboxylato and more readily for carboxylato than for hydroxido ligands. However, the cytotoxic properties are not only related to the reduction potentials but also to the rates of reduction [22,23], which are determined by the nature and concentrations of the reducing agents. Although it is generally assumed that small-molecules such as glutathione (GHS) or ascorbic acid are the cellular reducing agents for platinum(IV) compounds, the identity of in vivo reductants remains uncertain.

Thus, the platinum(IV) complexes are considered prodrugs that can be administered orally, due to their inertness and higher lipophilicity, and the two additional ligands can be used to improve the pharmacological properties in several ways such as increase the lipophilicity, co-deliver bioactive ligands, or attach the prodrug to delivery systems $[9,10$, 17,24]. There are no structure-activity rules for platinum(IV) complexes per se except 
that the platinum(II) precursor should be active $[9,18,25]$. A common strategy is to combine a known drug, analogous to cisplatin, with axial ligands that may introduce an additional function.

Complexes of platinum(IV) can be obtained via two-electron oxidation of the platinum(II) precursors [26]. The most widely used oxidizing agents are hydrogen peroxide and chlorine which produce trans addition products in which the equatorial ligands retain the stereochemistry of the starting platinum(II) compound (paths a and $\mathrm{b}$ in scheme 1). As shown in scheme 1, platinum(IV) dihydroxido compounds are important starting materials for the synthesis of dicarboxylato complexes (see path c in scheme 1) [27]. In view of the relevance of the axial ligands to adjust important parameters of the platinum(IV) such as reduction potential, lipophilicity and solubility, the synthesis of compounds with two distinct axial ligands has also been pursued [28-30]. This can be achieved by maintaining a free hydroxido group during the derivatization reaction of a trans-dihydroxido compound (see path $\mathrm{d}$ in scheme 1) or using an alcohol as a solvent for the $\mathrm{H}_{2} \mathrm{O}_{2}$ oxidative addition (see path e in scheme 1). In recent years, the use of easy to handle iodobenzene dichloride $\left(\mathrm{PhICl}_{2}\right)$ rather than chlorine gas facilitates the synthesis of dichloridoplatinum(IV) compounds [26]. In addition, the use of $\mathrm{PhICl}_{2}$ in aqueous acetone in the presence of tetrabutylammonium hydroxyde yields mixed transhydroxydo-chlorido platinum(IV) compounds [19]. Oxidative addition of bromine or iodine (path $\mathrm{f}$ in scheme 1) also produces the corresponding dihalidoplatinum(IV) complexes [31] while the use of N-halosuccinimides as oxidizing agent allows for the synthesis of both mono and dihalogenated platinum(IV) compounds [32,33]. 


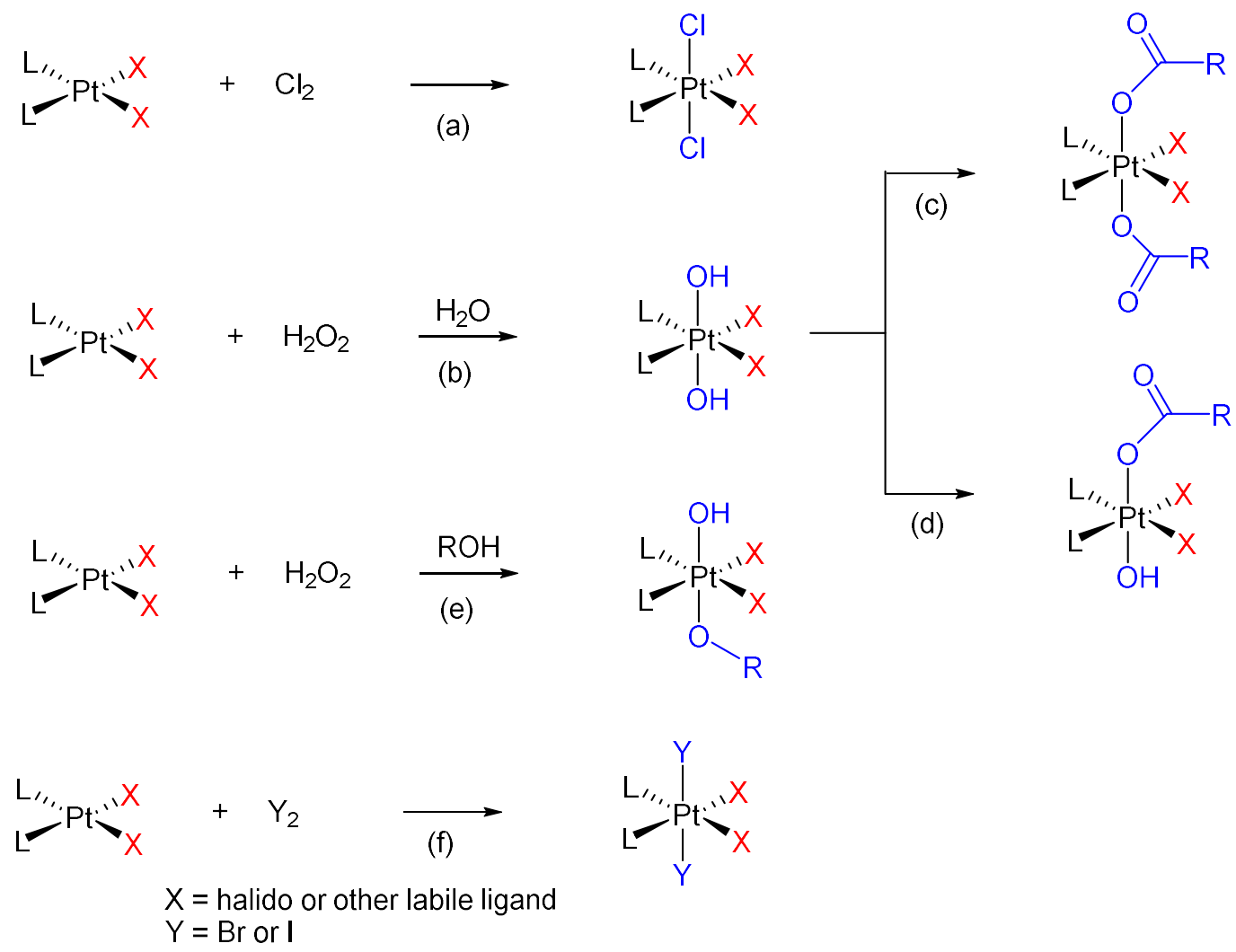

Scheme 1.- Several common strategies for the synthesis of platinum(IV) prodrugs. (a) oxidative addition of chlorine; (b) oxidative addition of hydrogen peroxide in water solution; (c) and (d) acetylation reactions of dihydroxido complexes to produce di and mono-carboxylato complexes; (e) oxidative addition of hydrogen peroxide in alcohol solution; (f) oxidative addition of bromine or iodine.

Although no platinum(IV) complex has been approved yet for clinical use, several platinum(IV) prodrugs such as ormaplatin (tetraplatin), iproplatin, satraplatin and LA-12 (shown in figure 3) have undergone clinical trials. Satraplatin is the platinum(IV) compound that advanced more in clinical trials and its behaviour indicate that platinum(IV) compounds are less inert than expected. The analyses of the plasma of patients indicated, in addition to the major metabolite which consists on the expected platinum(II) compound obtained from the loss of the two axial acetato ligands, the presence of two platinum(IV) metabolites in which one or two chlorido ligands were replaced by hydroxido ligands [10]. Moreover, although it is generally believed that 
platinum(IV) complexes can be reduced by low molecular weight biological reducing agents such as glutathione and ascorbic acid, recent studies carried out for satraplatin in cancer cells extracts revealed that high-molecular-weight intracellular components such as nicotinamide adenine dinucleotide (NADH) and cytochrome $\mathrm{c}$ are responsible for reduction of platinum(IV) to platinum(II) $[9,10,18]$. In addition, four square-planar platinum(II) reduction products, containing two chlorido, two acetato or one chlorido and one acetato ligands, were identified upon reduction of compounds cis,cis,trans$\left[\mathrm{PtCl}_{2}\left(\mathrm{NH}_{3}\right)\left(\mathrm{NH}_{2} \mathrm{R}\right)\left(\mathrm{CH}_{3} \mathrm{CO}_{2}\right)_{2}\right](\mathrm{R}=\mathrm{H}$, isopropyl or cyclohexyl), in contrast with the initial assumption that only the axial ligands are released in the reduction step [34].

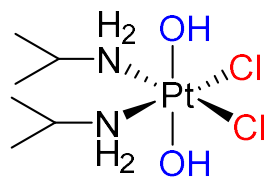

iproplatin<smiles>Cl[Te](Cl)(Cl)(Cl)(Cl)NC1CCCCC1</smiles>

tetraplatin<smiles>CC(=O)O[Cl+3](N)(Cl)P(N)(N)(Cl)OC(C)=O</smiles>

satraplatin<smiles>CC(=O)O[P+](N)(Cl)P(N)(Cl)(Cl)OC(C)=O</smiles>

LA-12

Fig. 3.- Platinum(IV) complexes that have entered clinical trials. Leaving groups in red, axial ligands in blue.

Platinum(IV) complexes have an enormous potential as anticancer agents, but many questions still need to be explored. They are generally considered as prodrugs for active platinum(II) species, but, in spite of the initial assumption that axial ligands were lost, as indicated above recent studies suggest that more than one reduction product is possible 
depending on the reducing agents. In addition, platinum(IV) compounds may be less inert than initially thought so that it is not totally certain that they are unable to bind to biomolecules without prior reduction [35,36]. The design of new types of platinum(IV) anticancer drug candidates is necessary in order to explore their biological activities and to develop more efficient antitumour agents.

\section{3.- ORGANOMETALLIC COMPOUNDS AS ANTITUMOR AGENTS}

Recent studies indicate that organometallic compounds are promising anticancer agents in spite of the initial idea that these compounds would be unstable under physiological conditions [37-40]. Organometallic compounds combine the properties of the metallic centre and the organic ligands, and the presence of strong $\mathrm{M}-\mathrm{C}$ bonds improves the stability of these compounds and greatly influences the lability of the other bonds present. In addition, organometallic compounds are easily modified and there is a wide range of C-donor ligands available so that rational design can be performed and structure-activity relationships can be established. Ferrocene, $\left[\mathrm{Fe}\left(\eta^{5}-\mathrm{C}_{5} \mathrm{H}_{5}\right)_{2}\right]$ was the first organometallic compound for which antiproliferative properties were tested and a wide range of metallocenes were also investigated [40]. Among those, titanocene dichloride $\left[\operatorname{Ti}\left(\eta^{5}\right.\right.$ $\left.\mathrm{C}_{5} \mathrm{H}_{5}\right)_{2} \mathrm{Cl}_{2}$ ] displays a good in-vivo anticancer activity [40]. Other classes of organometallic complexes for which the anticancer activity has been studied are metalarenes, in particular those of ruthenium(II) and other low-spin $\mathrm{d}^{6}$ metal centres such as osmium(II) or iridium(III), metal complexes with N-heterocyclic carbene, and cyclometallated complexes $[37,38]$. 


\section{1.- Cyclometallated platinum(II) compounds}

Cyclometallated compounds are appealing since they are easily obtained for a wide range of different ligands and metals [41-43]. Following the success of cisplatin in chemotherapies, not only a number of this type of platinum(II) compounds have been prepared in order to study their biological properties, but attention has also been focused on other metals such as $\mathrm{Pd}(\mathrm{II}), \mathrm{Au}(\mathrm{III}), \mathrm{Ru}(\mathrm{II}), \mathrm{Os}(\mathrm{II}), \mathrm{Rh}(\mathrm{III})$ or Ir(III). The most common ligands in these compounds are nitrogen donor either acting as bidentate $[\mathrm{C}, \mathrm{N}]$ or as tridentate $\left[\mathrm{C}, \mathrm{N}, \mathrm{N}^{\prime}\right],[\mathrm{C}, \mathrm{N}, \mathrm{C}]$ or $[\mathrm{C}, \mathrm{N}, \mathrm{S}]$ ligands in which the metallated carbon atom belongs to an aromatic group. These compounds are generally more stable than acyclic compounds, and the presence of aromatic planar groups might favour intercalative binding to DNA through non-covalent $\pi-\pi$ stacking interactions, while the labile positions in the coordination sphere of the metal favour covalent coordination to DNA as for cisplatin. Therefore a high cytotoxic activity may result from the combined effect of both modes of interaction operating for cyclometallated compounds.

A large number of cyclometallated platinum(II) compounds containing bidentate $[\mathrm{C}, \mathrm{N}]$ or tridentate $\left[\mathrm{C}, \mathrm{N}, \mathrm{N}^{\prime}\right]$ ligands have been screened against tumour cells and their properties can be easily modified by introducing different substituents in the aromatic ring of the cyclometallated ligand or by using different ancillary ligands [44-67]. In these compounds, the presence of a $\sigma(\mathrm{Pt}-\mathrm{C})$ bond increases the stability, thus allowing them to reach the cell unaltered. In addition, the lability of the ligands trans to a strong M-C bond increases so that covalent coordination to DNA is favoured. It is interesting to point out that the presence of $\mathrm{Pt}-\mathrm{C}$ bonds in platinum(II) complexes produces a sharp change over the substitution reactions mechanism so that dissociative pathway with the intermediacy 
of three-coordinate species is favoured over the associative pathway expected for squareplanar platinum compounds $[68,69]$. Moreover, several cyclometallated platinum(II) anticancer agents display luminescence properties which make them potential luminescent probes for DNA in living cells and also allows easy tracing of their cellular uptake and distribution by using fluorescence microscopy [70-72]. For instance, cyclometallated platinum(II) complexes such as $\mathbf{I}$ in figure 4 display high cytotoxicity to a panel of cancer cell lines and a strong phosphorescence [73].

\section{2.- Other types of organometallic platinum compounds}

In addition to cyclometallated platinum(II) compounds, other types of organometallic platinum compounds have been analysed as antitumor agents. These compounds generally break the traditional structure-activity rules described for cisplatin and analogues according to which two mutually cis non-labile and two mutually cis labile ligands complete the square-planar coordination of platinum(II). Some relevant examples of organoplatinum(II) compounds studied as potential anticancer agents are collected in Figure 4. 


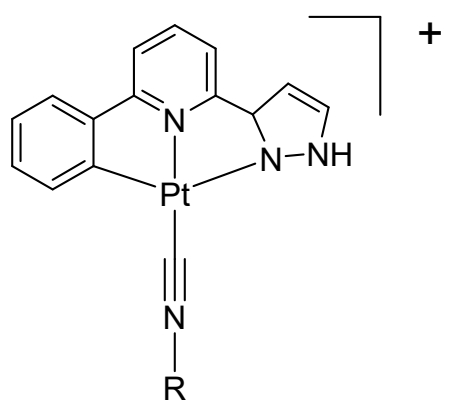

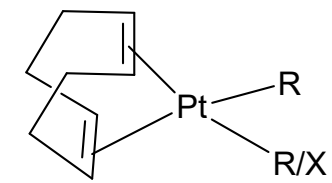

$\mathrm{R}=$ alkyl, aryl, alkynyl $\mathrm{X}=\mathrm{Cl}, \mathrm{Br}$

(II) $[75]$

$\mathrm{R}=\operatorname{aryl}$

(I) [73]

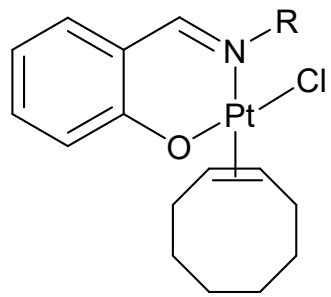

$\mathrm{R}=$ alkyl or aryl

(IV) [83]<smiles>N[PH](N)(C(F)(F)F)C(F)(F)F</smiles>

(III) $[81]$

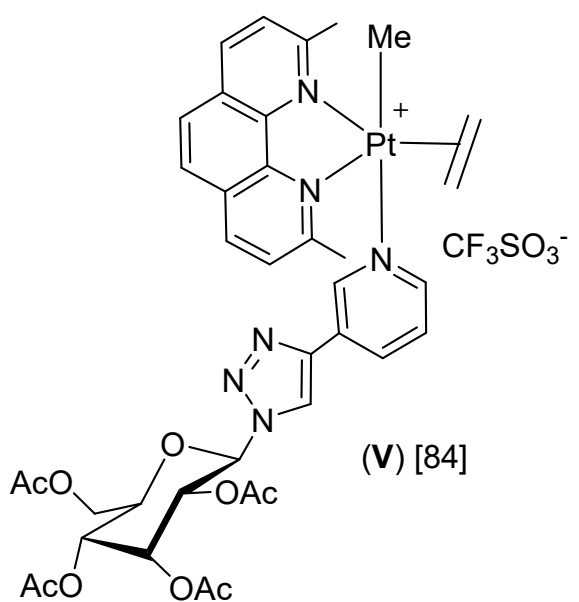

Fig. 4- Relevant examples of organometallic platinum(II) compounds investigated as potential anticancer agents.

Several organoplatinum(II) containing 1,4-cyclooctadiene (cod) and different organic ligands R such as alkyl, aryl or alkynyl have been prepared (see structure II in figure 4) and high antiproliferative activity has been found for compounds [PtRCl(cod)] and appreciable cytotoxicity for compounds $\left[\mathrm{PtR}_{2}(\operatorname{cod})\right]$ or [PtRR'(cod)]. Interestingly, while $\left[\mathrm{PtCl}_{2}(\mathrm{cod})\right]$ was not significantly active on HT-29 colon and MCF-7 breast cancer cells, $[\mathrm{PtMeCl}(\mathrm{cod})]$ exhibited promising antiproliferative effects [74-78].

Compounds containing inert pentafluoro or polyfluorophenyl anionic ligands instead of chlorido have received considerable attention since these groups confer a high lipophilicity to the obtained compounds which allows for easier cellular uptake and reduced side effects. Thus, several platinum(II) compounds of general formula $\left[\mathrm{PtR}_{2} \mathrm{~L}_{2}\right]$ or [PtRClL $L_{2}$ in which $\mathrm{R}$ is a polyfluorophenyl group and $\mathrm{L}$ is a neutral ligand display moderate to high cell growth inhibitory activity in spite of the presence of inert 
polyfluorophenyl groups bound to platinum [78-81]. An example of this type of compounds is shown in structure III of figure 4. Organometallic platinum $\pi$-complex dichlorido[ $\eta^{2}-\mathrm{N}, \mathrm{N}-$ dimethyl-(2-methylidene-cyclohex-1-yl)methylamino]platinum(II) displays a low cytotoxicity against Capan 1 and A431 cancer cell lines [82] and a family of organometallic platinum complexes containing $\pi$-coordinated cis-cyclooctene, with the structure IV in figure 4, gave promising results against MB231 breast or renal carcinoma (RCC) cancer cell lines [83]. A new class of five-coordinate platinum(II) compounds containing sugar ligands and exhibiting a high cytotoxicity has been recently reported (see structure $\mathbf{V}$ in figure 4) [84].

In spite of the great interest focussed on the anticancer properties of platinum(IV) compounds, there are very few reports concerning organometallic platinum(IV) compounds. A series of organometallic platinum(IV) compounds of general formulae I and II depicted in figure 5 display activity on leukaemia L1210 and on cisplatin resistant L1210/DDP cell lines although, according to the reduction potentials obtained by cyclic voltammetry, the polyfluorophenyl ligands greatly stabilise the platinum(IV) oxidation state and these compounds are difficult to be reduced [85]. Other examples of organoplatinum(IV) complexes studied as anticancer agents are compounds of general formula $\left[\mathrm{PtMe}_{2} \mathrm{X}_{2}\left({ }^{\mathrm{t}} \mathrm{Bubpy}\right)\right](\mathrm{X}=\mathrm{Cl}$ or $\mathrm{Br})($ structure III in figure 5) that were prepared by oxidative addition of $\mathrm{X}_{2}$ to the corresponding platinum(II) and display higher cytotoxic activity than cisplatin against Jurkat, K562 and MCF-7 cancer cell lines [86]. 


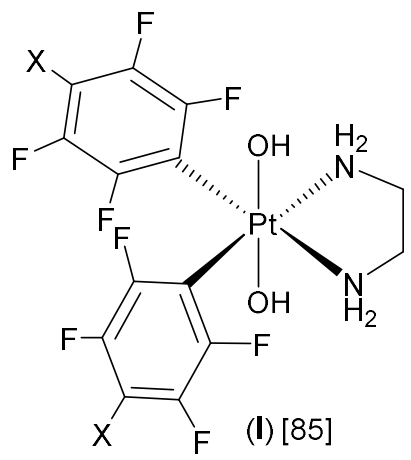

$\mathrm{X}=\mathrm{H}, \mathrm{F}$ or $\mathrm{CH}_{3} \mathrm{O}$

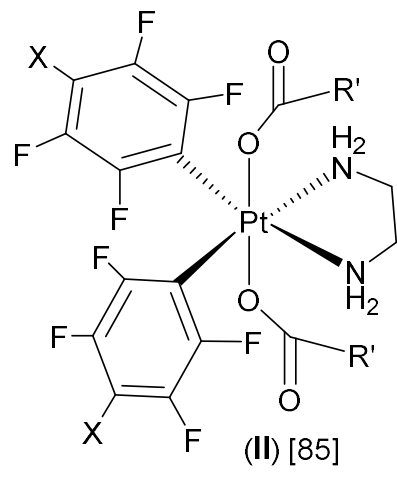

$\mathrm{X}=\mathrm{H}, \mathrm{F}$ or $\mathrm{CH}_{3} \mathrm{O}$

$\mathrm{R}^{\prime}=\mathrm{Me}, \mathrm{Et}, \mathrm{Pr}, \mathrm{Bu}, \mathrm{CH}_{2} \mathrm{Cl}$

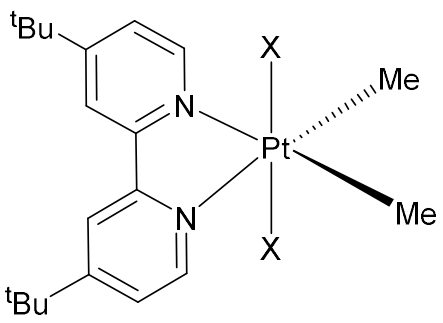

(III) [86]

$\mathrm{X}=\mathrm{Cl}, \mathrm{Br}$

Fig. 5- Relevant examples of organometallic platinum(IV) compounds investigated as potential anticancer agents.

\section{4.- CYCLOMETALLATED PLATINUM(IV) COMPOUNDS}

In spite of the great deal of attention focussed on platinum(IV) complexes (see section 2) and on cyclometallated platinum(II) compounds (see section 3.1), cyclometallated platinum(IV) compounds, which combine the properties imparted by the presence of a platinum(IV) centre and a cyclometallated ligand, have received very little attention.

Table 1 collects the antiproliferative activity on A-549 lung, MDA-MB-231 and MCF-7 breast, and HCT-116 for the studied cyclometallated platinum(IV) compounds (2a-2f, 3a3d and 4g-4i) [87-90] along with the data obtained for cyclometallated platinum(II) precursors (1a-1f) and the reference cisplatin.

\section{1.- Synthesis and properties of cyclometallated platinum(IV) compounds}

The synthesis of cyclometallated platinum(IV) compounds can be accomplished by intramolecular C-X bond activation from adequate platinum(II) substrates and ligands or by intermolecular oxidative addition to a previously synthesised cyclometallated platinum(II) compound. 
As initially reported by Anderson and Puddephatt [91] the use of electron-rich platinum precursors such as $\left[\mathrm{Pt}_{2} \mathrm{Me}_{4}\left(\mu-\mathrm{SMe}_{2}\right)_{2}\right]$ allows formation of cyclometallated platinum(II) or platinum(IV) compounds upon reaction with adequately designed ligands. The former arise from intramolecular $\mathrm{C}-\mathrm{H}$ bond activation followed by elimination of methane and the latter from intramolecular activation of $\mathrm{C}-\mathrm{X}$ bonds $(\mathrm{X}=\mathrm{F}, \mathrm{Cl}, \mathrm{Br})$ (see Scheme 2). This method allows one-step synthesis of tridentate [C,N,N'] cyclometallated platinum(IV) compounds such as $\left[\mathrm{PtMe}_{2} \mathrm{X}\left(\mathrm{RCH}=\mathrm{NCH}_{2} \mathrm{CH}_{2} \mathrm{NMe}_{2}\right](\mathrm{X}=\mathrm{F}, \mathrm{Cl}, \mathrm{Br} ; \mathrm{R}=\right.$ aryl) containing a $f a c-\mathrm{PtC}_{3}$ arrangement involving the metallated aryl carbon and two methyl ligands. This synthetic strategy allows the synthesis of a variety of cyclometallated compounds with different substituents on the aryl ring [92-94] or different size of the chelate $\left[\mathrm{N}, \mathrm{N}^{\prime}\right][95,96]$. Bidentate $[\mathrm{C}, \mathrm{N}]$ cyclometallated platinum(II) compounds of general formula $\left[\mathrm{PtMe}_{2} \mathrm{X}\left(\mathrm{C}_{6} \mathrm{H}_{4} \mathrm{CH}=\mathrm{NCH}_{2} \mathrm{Ar}\right) \mathrm{L}\right]$ in which $\mathrm{L}$ is a dialkylsulphide ligand which can be easily replaced by other ligands such as phosphines were also obtained following a similar method $[97,98]$.

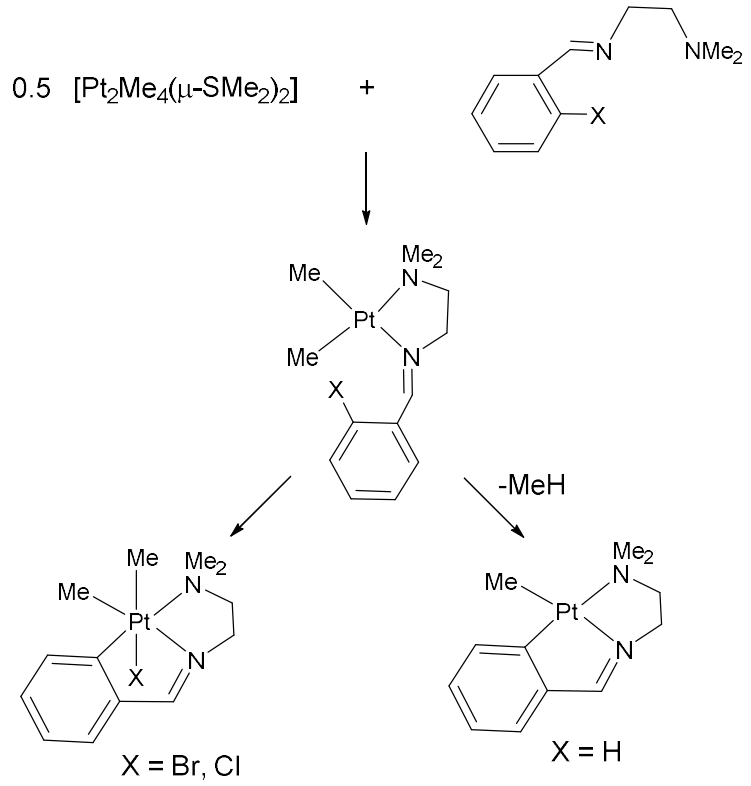


Scheme 2.- Synthesis of cyclometallated platinum(II) and platinum(IV) compounds from a dimethylplatinum(II) precursor [91-93].

In recent years, several diarylplatinum(II) compounds containing labile ligands such as dialkylsulphides have also been tested as metallating agents for the same class of dinitrogen ligands and these reactions produced [C,N,N'] cyclometallated platinum(IV) or platinum(II) compounds such as $\left[\mathrm{PtAr}_{2} \mathrm{X}\left(\mathrm{RCH}=\mathrm{NCH}_{2} \mathrm{CH}_{2} \mathrm{NMe}_{2}\right)\right]$ or $\left[\operatorname{PtAr}\left(\mathrm{RCH}=\mathrm{NCH}_{2} \mathrm{CH}_{2} \mathrm{NMe}_{2}\right)\right]$ depicted in scheme $3[88,99,100]$.

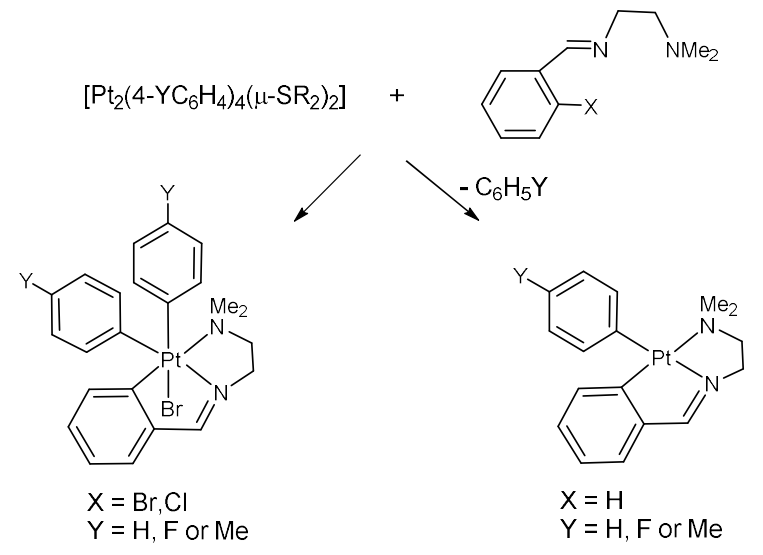

Scheme 3. - Synthesis of cyclometallated platinum(II) and platinum(IV) compounds from diarylplatinum(II) precursors [99].

Cyclometallated platinum(IV) compounds such as those shown in schemes 2 and 3 display some characteristic features. In solid state, the analysis of the structures by X ray crystallography $[92,101]$ indicate a $f a c-\mathrm{PtC}_{3}$ geometry of the three $\mathrm{C}$-donor ligands and a $m e r-\left[\mathrm{C}, \mathrm{N}, \mathrm{N}^{\prime}\right]$ arrangement of the tridentate ligand. In solution, two isomers, both with the $f a c-\mathrm{PtC}_{3}$ geometry, and with the [C,N,N'] ligand either in mer of fac arrangement are possible. Calculations carried out for compounds $\left[\mathrm{PtMe}_{2} \mathrm{X}\left(\mathrm{C}, \mathrm{N}, \mathrm{N}^{\prime}\right)\right]$ indicated a slightly higher stability for the mer versus the $f a c-\left[\mathrm{C}, \mathrm{N}, \mathrm{N}^{\prime}\right]$ ligand arrangement [92]. 
On the other hand, intermolecular oxidative addition on cisplatin and analogues to prepare platinum(IV) prodrugs has been carried out mainly with oxidizing agents such as halogen or hydrogen peroxide (see scheme 1) [18,26,31]. It is generally observed that the set of equatorial ligands of the resulting platinum(IV) compounds retain the stereochemistry of the starting platinum(II) compound while the new ligands occupy the axial positions [102, 103]. Similar oxidative addition reactions can yield cyclometallated platinum(IV) compounds from the corresponding cyclometallated platinum(II) compounds and this type of oxidative addition reactions is well established for reagents such as chlorine, iodine or alkyl halides [102, 104-109].

Compounds 2a-2f (see Table 1) [87,90] were prepared from oxidative addition of methyl iodide on the corresponding cyclometallated platinum(II) compounds 1a-1f, that were obtained following reported procedures $[95,96]$. Octahedral platinum(IV) compounds in which the new ligands are mutually trans were obtained and the ${ }^{1} \mathrm{H}$ NMR spectra indicated in most cases the presence of one single isomer in which the $\mathrm{NMe}_{2}$ methyl groups and the $\mathrm{CH}_{2}$ proton atoms are diastereotopic due to the absence of a symmetry plane. Only for $\mathbf{2} \mathbf{b}$, the presence in an amount of less than $10 \%$ of a second isomer arising from mer to $f a c-\left[\mathrm{C}, \mathrm{N}, \mathrm{N}^{\prime}\right]$ isomerization was observed in the ${ }^{1} \mathrm{H}$ NMR spectrum. For the phosphine derivative $\mathbf{2 f}$ initial trans oxidative addition is followed by complete isomerization to place the bulky phosphine ligand in an axial position trans to the methyl group. The oxidative addition of iodine on [C,N,N'] cyclometallated platinum(II) compounds 1a-1d produced compounds 3a-3d, while the reactions of [C,N] cyclometallated platinum(II) compounds $\mathbf{1 e}$ and $\mathbf{1 f}$ gave very insoluble compounds that were not studied further. 
Compounds $\mathbf{4 g - 4 i}$ were prepared in a straightforward process consisting of intramolecular C-X bond activation $(\mathrm{X}=\mathrm{Cl}$ or $\mathrm{Br})$ of ligands $2-\mathrm{BrC}_{6} \mathrm{H}_{4} \mathrm{CH}=\mathrm{NCH}_{2} \mathrm{CH}_{2} \mathrm{NMe}_{2}$ or 2,6$\mathrm{Cl}_{2} \mathrm{C}_{6} \mathrm{H}_{3} \mathrm{CH}=\mathrm{NCH}_{2} \mathrm{CH}_{2} \mathrm{NMe}_{2}$ upon reaction with diarylplatinum substrates $\left[\mathrm{Pt}_{2}(4-\right.$ $\left.\left.\mathrm{FC}_{6} \mathrm{H}_{4}\right)_{4}\left(\mu-\mathrm{SEt}_{2}\right)_{2}\right]$ or $\left[\mathrm{Pt}_{2}\left(4-\mathrm{MeC}_{6} \mathrm{H}_{4}\right)_{4}\left(\mu-\mathrm{SEt}_{2}\right)_{2}\right]$ (see scheme 3) $[88,89]$.

As a whole, the set of [C,N,N']-cyclometallated platinum(IV) compounds under study include complexes with two axial ligands of the same or of different nature, which contain a variable number of labile positions such as the halogenido ligands or the dimethylamino fragment of the tridentate ligands, and one, two or three carbon atoms. It is interesting to point out that the presence of an increasing number of $\mathrm{Pt}-\mathrm{C}$ bonds produces more labile complexes in spite of the inertness attributed to the $\mathrm{t}_{2 \mathrm{~g}}{ }^{6}$ electronic configuration and that platinum(IV) complexes containing a $f a c-\mathrm{PtC}_{3}$ geometry are considered as "quasi-labile" systems $[110,111]$.

The stability of cyclometallated platinum(IV) compounds $\mathbf{2 b - 2 d}$ and $\mathbf{4 g - 4 i}$ in the aqueous biological media was evaluated by recording the ${ }^{1} \mathrm{H}$ NMR spectra of the compounds (1 $\mathrm{mM}$ ) in $50 \mathrm{mM}$ phosphate buffer (in $\mathrm{D}_{2} \mathrm{O}, \mathrm{pD}$ 7.40) with 2 drops of deuterated DMSO to solubilize the compounds in the media. Under these conditions, one or more solvato species arising from substitution of the labile ligands are detected, and remain stable for several days. Unfortunately, the low solubility of compounds 3a-3d arising from oxidative addition of iodine and containing just one C-donor ligand did not allow analogous studies for these compounds.

The reactions of compounds containing two or three C-donor ligands including one axial

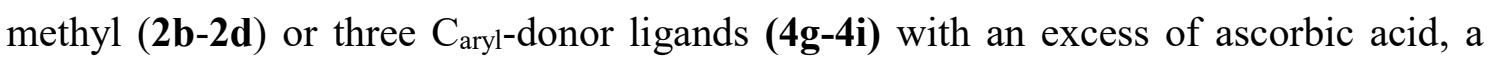
biologically relevant reducing agent, were monitored by ${ }^{1} \mathrm{H}$ NMR spectroscopy under 
analogous conditions and no evidence of reduction to the corresponding platinum(II) compounds was observed, although new species, different to the solvato species initially formed, are detected and assigned to coordination of ascorbic acid to platinum. Analogous experiments with other reducing agents such as glutathione or cysteine were carried out for $\mathbf{2 d}$ and indicated coordination of these molecules to platinum(IV) without evidence of reduction. In line with these results, the large negative values of the reduction potentials obtained by cyclic voltammetry for compounds $\mathbf{4 g - 4 i}$ are in the same range than those reported for platinum(IV) complexes with polyfluoroaryl ligands [85] and much lower than that reported for compounds such as tetraplatin, satraplatin or iproplatin, thus implying that compounds $\mathbf{4 g - 4 i}$ are reluctant to be reduced [89].

On the other hand, recent studies indicated that compound $\left[\mathrm{PtCl}_{3}(4-\right.$ $\left.\mathrm{ClC}_{6} \mathrm{H}_{4} \mathrm{CH}=\mathrm{N}\left(\mathrm{CH}_{2}\right)_{3} \mathrm{NMe}_{2}\right]$ arising from oxidative addition of chlorine to compound $\mathbf{1 a}$ and containing just one $\mathrm{C}$-donor ligand is reduced by cysteine, glutathione and thiolactic acid and the kinetics of these reactions were monitored by UV-Vis spectrophotometry. In all cases, two consecutive reaction steps were found to occur, the platinum(IV) to platinum(II) reduction and the substitution of the remaining chlorido ligand by the reduction agent [112].

These results indicate that the number of $\mathrm{C}$-donor ligands in cyclometallated platinum(IV) compounds could be decisive in the ease of platinum(IV) to platinum(II) reduction and thus in the mode of action as drugs or prodrugs of these compounds. 


\section{2.- Biological studies of cyclometallated platinum(IV) compounds}

The antiproliferative activity of the studied cyclometallated platinum(IV) compounds was tested on A-549 lung, MDA-MB-231 and MCF-7 breast, and HCT-116 cancer cell lines (Table 1 and figure 6). The [C,N,N'] cyclometallated platinum(IV) compounds obtained from platinum(II) precursors 1a-1d exhibited remarkable cytotoxicity in all the carcinoma cell lines studied. In particular, compounds $\mathbf{2 a - 2 d}$ with methyl and iodido axial ligands showed the lowest $\mathrm{IC}_{50}$ values, in most cases lower than those obtained for the corresponding precursors $\mathbf{1 a - 1 d}$. The activity of compounds $\mathbf{3 a}, \mathbf{3 b}$ and $\mathbf{3 d}$ containing two axial iodido ligands is similar to that of the parent platinum(II) compounds, while the cytotoxicity of compound 3c containing three iodido ligands is lower [87,90]. For compounds $4 \mathbf{g}$, $4 \mathbf{h}$ and $\mathbf{4 i}$ containing a $f a c-\mathrm{PtC}_{3}$ arrangement and a [C,N,N'] ligand derived from ethylenediamine, the results indicated that the fluorinated derivative $\mathbf{4 g}$ is less potent than $\mathbf{4 h}$ and $\mathbf{4 i}$. Finally, compounds $\mathbf{2 e}$ and $\mathbf{2 f}$ containing a $[\mathrm{C}, \mathrm{N}]$ metallacycle and a neutral ligand such as $\mathrm{SEt}_{2}$ or $\mathrm{PPh}_{3}$ ligand are much less active than the [C,N,N'] analogue $\mathbf{2 d}$. 
Table 1. Antiproliferative activity $\left(\mathrm{IC}_{50} \mu \mathrm{M}\right)$ on A-549 lung, MDA-MB-231 and MCF-7 breast, and HCT-116 cancer cell lines for the studied cyclometallated platinum(II) precursors (1a-1f), cyclometallated platinum(IV) compounds (2a-2f, 3a-3d, 4g-4i) and cisplatin. ${ }^{\mathrm{a}}$

\begin{tabular}{|c|c|c|c|c|}
\hline Platinum(II) compounds & A-549 & MDA-MB-231 & MCF-7 & НCT-116 \\
\hline $1 \mathbf{a}$ & $5.48 \pm 3.49$ & $8.30 \pm 3.60$ & $7.69 \pm 0.750$ & $6.29 \pm 0.34$ \\
\hline $1 b$ & $9.62 \pm 2.14$ & $7.34 \pm 0.59$ & $31.26 \pm 0.51$ & $10.58 \pm 0.22$ \\
\hline $1 \mathrm{c}$ & $6.25 \pm 2.66$ & $10.18 \pm 3.42$ & $10.23 \pm 0.48$ & $7.05 \pm 0.18$ \\
\hline $1 d$ & $9.80 \pm 0.32$ & $7.71 \pm 1.00$ & $13.83 \pm 3.37$ & $6.48 \pm 1.27$ \\
\hline 1e & $6.45 \pm 0.33$ & $5,52 \pm 0.16$ & $10.16 \pm 0.58$ & $3.99 \pm 0.38$ \\
\hline
\end{tabular}




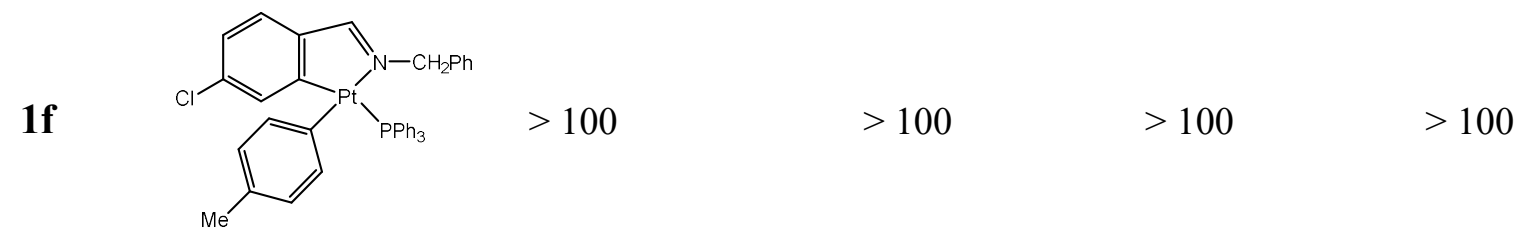

$2 a$

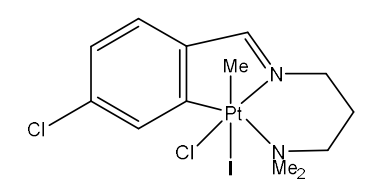

$\begin{array}{llll}2.46 \pm 0.24 & 2.34 \pm 0.33 & 12.39 \pm 0.76 & 5.43 \pm 0.13\end{array}$

$2 \mathbf{b}$

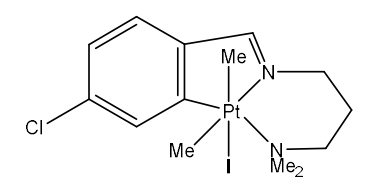

$2.62 \pm 0.27 \quad 2.06 \pm 0.51 \quad 7.86 \pm 0.72 \quad 2.28 \pm 0.26$

2c<smiles>CC1(I)N2CCCN1c1cc(Cl)ccc1C2</smiles>

$1.42 \pm 0.13 \quad 3.45 \pm 1.55$

$6.72 \pm 0.43$

$1.26 \pm 0.18$

2d

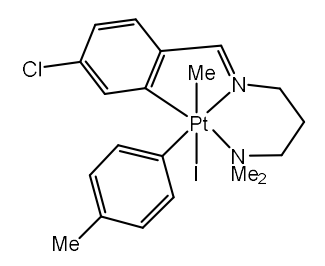

\section{$3.40 \pm 1.74$}

$1.58 \pm 0.58$

$10.02 \pm 3.69$

$1.77 \pm 0.59$

$2 \mathrm{e}$<smiles>CCN1CC2C=CC(Cl)=CC2[P+]1(CC)c1ccc([N+](=O)[O-])cc1</smiles>

$75.47 \pm 12.97 \quad 24.65 \pm 2.92$

$>100$

$8.57 \pm 0.87$ 


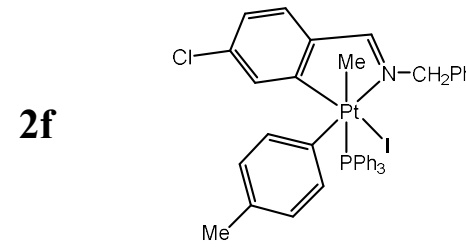

$$
\begin{array}{llll}
>100 & 38.29 \pm 7.44 & >100 & 30.54 \pm 6.87
\end{array}
$$

3a<smiles>CP12(Cl)c3cc(Cl)ccc3C1N1CCCN2C1</smiles>

$\begin{array}{llll}4.69 \pm 3.61 & 5.11 \pm 2.21 & 8.42 \pm 0.41 & 5.06 \pm 0.10\end{array}$

$3 b$<smiles>CC1(C)N=Cc2ccc(Cl)cc21</smiles>

$\begin{array}{llll}6.67 \pm 1.30 & 7.25 \pm 0.23 & 7.65 \pm 0.11 & 3.95 \pm 1.62\end{array}$

$3 c$<smiles>Clc1ccc2c(c1)P1(I)(I)C3N(CCCN31)C2</smiles>

$23.0 \pm 2.98$

$14.10 \pm 4.07$

$32.00 \pm \mathrm{nd}$

$12.11 \pm 0.69$

3d<smiles>Cc1ccc(CN2CCCN3C(C)(c4ccc(C)cc4)C23C)cc1</smiles>

\section{$9.69 \pm 0.43$}

$7.25 \pm 1.68$

$11.08 \pm 0.83$

$5.13 \pm 0.03$

$4 g$

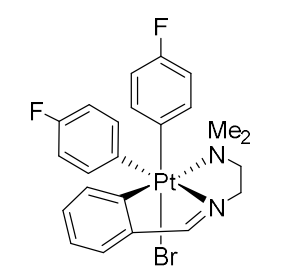

$11.6 \pm 2.2$

$11.8 \pm 0.5$

$19.3 \pm 2.2$

c

4h

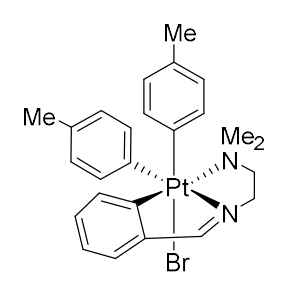

$4.5 \pm 0.6$

$2.3 \pm 0.2$

$7.3 \pm 0.9$

c 
${ }^{a}$ Data are shown as the mean values of two experiments performed in triplicate with the corresponding standard deviations. ${ }^{\mathrm{b}}$ Cisplatin $\left(\mathrm{cis}-\left[\mathrm{PtCl}_{2}\left(\mathrm{NH}_{3}\right)_{2}\right]\right)$ is taken as reference compound and values are taken from reference [87]. ${ }^{\mathrm{c}}$ Not studied.

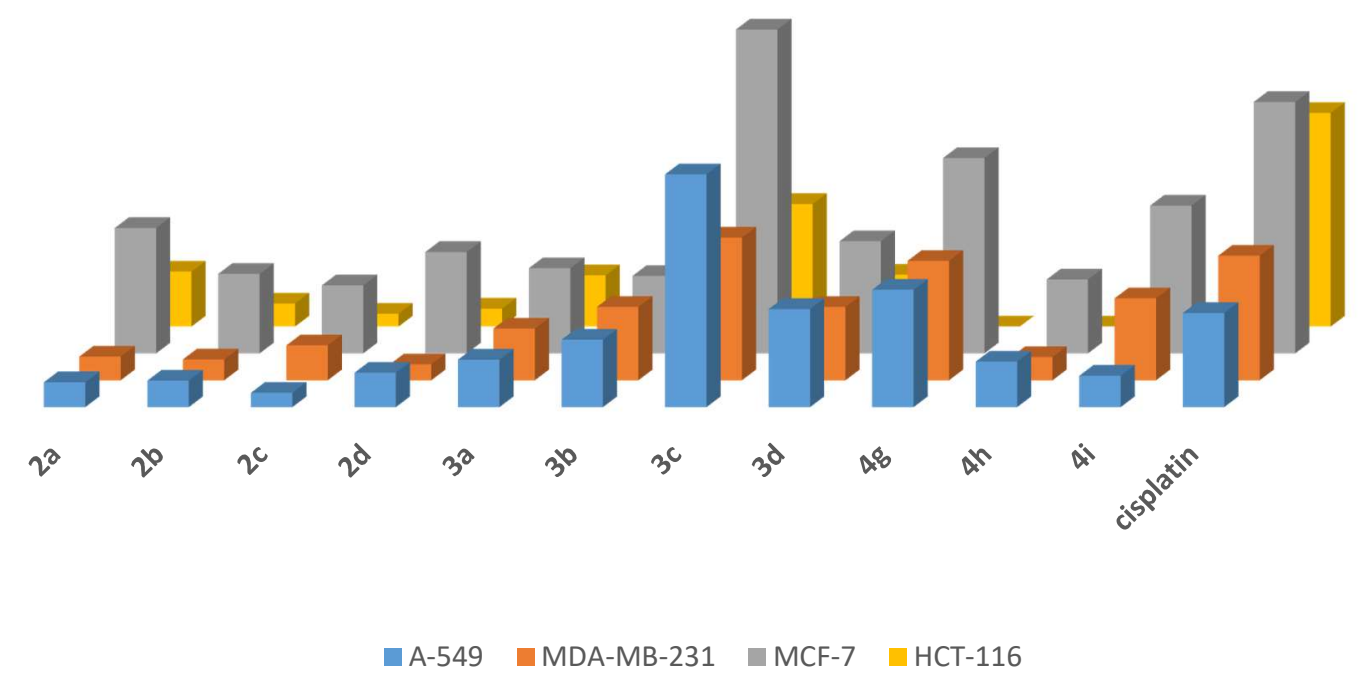

Fig. 6- Antiproliferative activity $\left(\mathrm{IC}_{50} \mu \mathrm{M}\right)$ of $\left[\mathrm{C}, \mathrm{N}, \mathrm{N}^{\prime}\right]$ cyclometallated platinum(IV) compounds 2a-2d, 3a-3d, 4g-4i, and cisplatin against A-549 lung, MDA-MB-231 and MCF-7 breast and HCT-116 colon cancer cell lines. 
The interaction of cyclometallated platinum(IV) compounds with DNA was assessed by their ability to modify the electrophoretic mobility of the supercoiled closed circular (sc) and the open circular $(o c)$ forms of pBluescript $\mathrm{SK}^{+}$plasmid DNA. Compounds 2a-2c, $\mathbf{2 e}, \mathbf{3 a}-\mathbf{3 d}$ and $\mathbf{4 i}$ did not modify the DNA tertiary structure, while compounds $\mathbf{2 d}, \mathbf{2 f}, \mathbf{4 h}$ and $\mathbf{4 g}$ induce significant changes in the mobility of plasmid DNA, altering the DNA tertiary structure as the standard reference cisplatin, although at higher concentrations (see Table 2). Although there is not a clear evidence, the obtained results point to the fact that the presence of bulky equatorial substituents such as aryl ligands (2d and $\mathbf{2 f}$ ) instead of smaller ligands (2a-2c) and of iodido or bromido $(\mathbf{4 g}, \mathbf{4 h})$ axial ligands rather than chlorido (4i) favour the covalent binding to DNA in agreement with a dissociatively activated substitution mechanism for this type of compounds [111].

On the other hand, the fact that compounds $\mathbf{2 a - 2 c}$ did not modify the DNA migration in spite of their low $\mathrm{IC}_{50}$ values points to other mechanisms of action or biomolecular targets. To evaluate the ability of the investigated cyclometallated platinum(IV) complexes to intercalate into DNA, a topoisomerase-based gel assay was performed for most of the studied complexes (see Table 2). Supercoiled pBluescript plasmid DNA was incubated in the presence of topoisomerase I at increasing concentrations of the studied compounds. None of the tested compounds prevent unwinding of DNA by the action of topoisomerase I, indicating that these compounds are neither topoisomerase I inhibitors nor intercalators. Although intercalative binding to DNA through non-covalent $\pi-\pi$ stacking interactions is favoured in planar platinum(II) cyclometallated compounds, such interactions are less likely for octahedral platinum(IV) compounds. To study an alternative biomolecular target, a topoisomerase II $\alpha$-based gel assay was also performed for compounds $\mathbf{2}$ and $\mathbf{3}$ 
using a similar procedure than that reported above for topoisomerase I. Several of these compounds showed considerable topoisomerase II $\alpha$ inhibitory activity, a remarkable result since this enzyme is the target for several anticancer agents.

Cathepsin B inhibition assay was also performed for most of the compounds studied since this cysteine metalloprotease has been proposed to participate in metastasis, angiogenesis, and tumour progression. The compounds did not present significant inhibitory activity against cathepsin B except for compound 3a which shows a moderate activity.

Reactive oxygen species (ROS) are by-products of cell metabolism such as hydrogen peroxide, superoxide, hydroxyl radical and singlet oxygen. Although high ROS levels might produce cell senescence or apoptosis, cancer cells are able to maintain higher ROS levels while evading apoptosis. As part of their biological activities in cancer cells certain platinum complexes are able to induce elevated ROS levels to an extent which cancer cells can no longer evade apoptosis. As part of the study of the cytotoxic effect of the cyclometallated platinum(IV) compounds, ROS generation on A-549 or on HCT-116 cancer cells was tested for selected compounds (see Table 2). In most cases, a significantly increased ROS generation occurs in agreement with previous studies that reported enhanced ROS generation in cancer cells as a response to platinum(IV) complexes $[113,114]$. 
Table 2. Summary of biological studies carried out for cyclometallated platinum(IV) compounds $2 \mathbf{a}-\mathbf{2 f}, \mathbf{3 a - 3 d}, \mathbf{4 g - 4 i}{ }^{a}$

\begin{tabular}{cccccc}
\hline Compound & DNA $^{b}$ & Topo I $^{c}$ & Topo II $^{d}$ & Cathepsin $^{e}$ & ROS $^{f}$ \\
\hline $\mathbf{2 a}$ & $\mathrm{N}$ & $\mathrm{N}$ & $\mathrm{N}$ & $\mathrm{N}$ & $g$ \\
$\mathbf{2 b}$ & $\mathrm{N}$ & $\mathrm{N}$ & $20 \mu \mathrm{M}$ & $\mathrm{N}$ & $\mathrm{N}$ \\
$\mathbf{2 d}$ & $100 \mu \mathrm{M}$ & $\mathrm{N}$ & $10 \mu \mathrm{M}$ & $\mathrm{N}$ & $\mathrm{Y}$ \\
$\mathbf{2 e}$ & $\mathrm{N}$ & $\mathrm{N}$ & $100 \mu \mathrm{M}$ & $\mathrm{N}$ & $g$ \\
$\mathbf{2 f}$ & $25 \mu \mathrm{M}$ & $\mathrm{N}$ & $25 \mu \mathrm{M}$ & $\mathrm{N}$ & $g$ \\
$\mathbf{3 a}$ & $\mathrm{N}$ & $\mathrm{N}$ & $20 \mu \mathrm{M}$ & $\mathrm{Y}$ & $g$ \\
$\mathbf{3 b}$ & $\mathrm{N}$ & $\mathrm{N}$ & $\mathrm{N}$ & $\mathrm{N}$ & $g$ \\
$\mathbf{3 c}$ & $\mathrm{N}$ & $\mathrm{N}$ & $100 \mu \mathrm{M}$ & $\mathrm{N}$ & $g$ \\
$\mathbf{3 d}$ & $\mathrm{N}$ & $\mathrm{N}$ & $50 \mu \mathrm{M}$ & $\mathrm{N}$ & $\mathrm{Y}$ \\
$\mathbf{4 g}$ & $200 \mu \mathrm{M}$ & $g$ & $g$ & $\mathrm{~N}$ & $g$ \\
$\mathbf{4 h}$ & $100 \mu \mathrm{M}$ & $g$ & $g$ & $\mathrm{~N}$ & $\mathrm{Y}$ \\
\hline $\mathbf{4 i}$ & $\mathrm{N}$ & $\mathrm{N}$ & $g$ & $\mathrm{Y}$ & $\mathrm{Y}$ \\
\hline
\end{tabular}

\footnotetext{
${ }^{a}$ See references $[87,89,90]$ for further information; ${ }^{b}$ In this column $\mathrm{N}$ indicates that the compound does not modify the plasmid DNA electrophoretic mobility; for compounds that alter the mobility of DNA the required concentration is indicated; ${ }^{\mathrm{c}}$ In this column $\mathrm{N}$ indicates that the compound is neither intercalator nor topoisomerase I inhibitor; ${ }^{d} \mathrm{In}$ this column $\mathrm{N}$ indicates that the compound is not a topoisomerase II $\alpha$ inhibitor; for compounds that show inhibitory activity the required concentration is indicated; ${ }^{e}$ In this column, $\mathrm{Y}$ indicates that the compound inhibits cathepsin $\mathrm{B}$ and $\mathrm{N}$ indicates that the compound does not show cathepsin B inhibitory activity;. ${ }^{f}$ In this column $\mathrm{Y}$ indicates that the compound cause significant ROS generation after incubation with the cancer cell line A-549 (2c, $4 \mathbf{h}, \mathbf{4 i})$ or HCT-116 (2d, 3d, $\mathbf{4 h}, \mathbf{4 i})$ and $\mathrm{N}$ indicates that the compound does not cause a significant increase in ROS production. ${ }^{g}$ Not studied.
} 


\section{CONCLUSIONS}

Several cyclometallated platinum(IV) compounds have been prepared by intermolecular oxidative addition of either methyl iodide (2a-2f) or iodine (3a-3d) to the corresponding cyclometallated platinum(II) compounds. In addition, compounds $\mathbf{4 h - 4 i}$ were prepared by intramolecular oxidative addition of $\mathrm{C}-\mathrm{Br}$ or $\mathrm{C}-\mathrm{Cl}$ bonds of imine ligands to diarylplatinum(II) precursors. The tridentate [C,N,N']-cyclometallated platinum(IV) compounds exhibited a remarkable cytotoxicity effectiveness against a panel of human adenocarcinoma (A-549 lung, HCT-116 colon, MDA-MB-231 and MCF-7 breast, and HCT-116) cell lines while bidentate $[\mathrm{C}, \mathrm{N}]$-cyclometallated platinum(IV) compounds are less active. ${ }^{1} \mathrm{H}$ NMR experiments carried out in a buffered aqueous medium for compounds $\mathbf{2 b - 2 d}$ and $\mathbf{4 g - 4 i}$ containing two or three C-donor atoms in the presence of common biologically relevant reducing agents indicated coordination of these molecules to platinum(IV) without reduction to platinum(II) species. Compounds $\mathbf{2 d}, \mathbf{2 f}, \mathbf{4 h}$ and $\mathbf{4 g}$ induce significant changes in the mobility of plasmid DNA, altering the DNA tertiary structure as the standard reference cisplatin, although at higher concentrations. None of the compounds tested were topoisomerase I inhibitors, but several compounds $(\mathbf{2 b}, \mathbf{2 d}$, 2f, 3a, and to a lesser extent $\mathbf{2 e}, \mathbf{3 c}$ or $\mathbf{3 d}$ ) showed topoisomerase II $\alpha$ inhibitory activity or the ability to induce ROS generation $(\mathbf{2 c}, \mathbf{2 d}, \mathbf{3 d}, \mathbf{4 h}$ or $\mathbf{4 i})$. As a whole, the obtained results indicate that some of the [C,N,N']-cyclometallated platinum(IV) compounds here described display a multitarget nature and a high potential to be used in cancer chemotherapy. The stability towards reduction, the lability and the biological properties of these compounds can be easily tuned by a careful choice of the nature of the ligands 
completing the octahedral coordination around the platinum centre or the substituents in the aryl ring. In particular, further studies in our group will be aimed at analysing the effect of the presence of one, two or three Pt-C bonds in the properties and in the mode of action as drugs or prodrugs of this new class of promising antitumour agents

\section{Dedication and Acknowledgments}

This paper is dedicated to Professor Richard J. Puddephatt on the occasion of his 75th birthday in deep appreciation of his many outstanding contributions to Organometallic Chemistry.

The author thanks all the students and colleagues who contributed to develop the chemistry and the biological studies of cyclometallated platinum(IV) compounds summarised in this article. This work was supported by the Ministerio de Economia $y$ Competitividad (Projects CTQ-2015-65040-P, CTQ-2015-65707-C2-1/FEDER and CTQ2017-90802-REDT). 


\section{REFERENCES}

[1] A. Klein, Stayin' Alive-Organoplatinum complexes. Inorganics 3 (2015) 155-159.

[2] J.A. Labinger, Platinum-catalyzed C-H functionalization, Chem. Rev. 117 (2017), 8483-8496.

[3] B. Rosenberg, Fundamental studies with cisplatin, Cancer 55 (1985) 2303-2316.

[4] N.J. Wheate, S. Walker, G.E. Craig, R. Oun. The status of platinum anticancer drugs in the clinic and in clinical trials. Dalton Trans. 39 (2010) 8113-8127.

[5] T.C. Johnstone, K. Suntharalingam, S.J. Lippard, The next generation of platinum drugs: Targeted $\mathrm{Pt}(\mathrm{II})$ agents, nanoparticle delivery, and $\mathrm{Pt}(\mathrm{IV})$ prodrugs, Chem. Rev. 116 (2016) 3436-3486.

[6] L. Kelland, The resurgence of platinum-based cancer chemotherapy, Nature Reviews 7 (2007) 573-584.

[7] A.M. Montaña, C. Batalla, The rational design of anticancer platinum complexes: the importance of the structure-activity relationship, Current Med. Chem. 16 (2009) 2235-2260.

[8] A.V. Klein, T.W. Hambley, Platinum drug distribution in cancer cells and tumors, Chem. Rev. 109 (2009) 4911-4920.

[9] R.G. Kenny, S.W. Chuah, A. Crawford, C.J. Marmion, Platinum (IV) prodrugs A step closer to Ehrlich's vision ?, Eur. J. Inorg. Chem. (2017) 1596-1612. 
[10] D. Gibson, Platinum(IV) anticancer prodrugs - hypotheses and facts, Dalton Trans. (2016) 12983-12991.

[11] E. Wexselblatt, D. Gibson, What do we know about the reduction of Pt(IV) prodrugs?, J. Inorg. Biochem. 117 (2012) 220-229.

[12] N. Farrell, L.R. Kelland, J.D. Roberts, M. van Beusichem, Activation of the trans geometry in platinum antitumor complexes: A survey of the cytotoxicity of trans complexes containing planar ligands in murine L1210 and human tumor panels and studies of their mechanisms of action, Cancer Res. 52 (1992), 5065-5072.

[13] G. Zhu, M. Myint, W.H. Ang, L. Song, S.J. Lippard, Monofuncional platinum DNA adducts are strong inhibitors of transcription and substrates for nucleotide excision repair in live mammalian cells, Cancer Res. 72 (2012) 790-800.

[14] K.M. Deo, B.J. Pages, D.L. Ang, C.P. Gordon, J.R. Aldrich-Wright, Transition Metal intercalators as anticancer agents-Recent advances, Int. J. Mol. Sci. 17 (2016) 1818-1834.

[15] N. Farrell, Non-classical platinum antitumor agents: perspectives for design and development of new drugs complementary to cisplatin, Cancer Invest. 11 (1993) $578-589$.

[16] N. Farrell, Y. Qu, M.P. Hacker, Cytotoxicity and antitumor activity of bis(platinum) complexes. A novel class of platinum complexes active in cell lines resistant to both cisplatin and 1,2-diaminocyclohexane complexes, J. Med. Chem. 33 (1990) 2179-2184. 
[17] M.D. Hall, T.W. Hambley, Platinum (IV) antitumour compounds: their bioinorganic chemistry, Coord. Chem. Rev. 232 (2002) 49-67.

[18] T.C. Johnstone, J.J. Wilson, S.J. Lippard, Monofunctional and higher-valent platinum anticancer agents, Inorg. Chem. 52 (2013) 12234-12249.

[19] S-X. Guo, D.N. Mason, S.A. Turland, E.T. Lawrenz, L.C. Kelly, G.D. Fallon, B.M. Gatehouse, A.M. Bond, G. B. Deacon, A.R. Battle, T.W. Hambley, S.Rainone, L.K. Webster, C. Cullinane, Systematic differences in electrochemical reduction of the structurally characterized anti-cancer platinum(IV) complexes $\left[\mathrm{Pt}\left\{\left(\left(\mathrm{pHC}_{6} \mathrm{~F}_{4}\right) \mathrm{NCH}_{2}\right)_{2}\right\}(\text { pyridine })_{2} \mathrm{Cl}_{2}\right],\left[\mathrm{Pt}\left\{\left(\left(\mathrm{pHC}_{6} \mathrm{~F}_{4}\right) \mathrm{NCH}_{2}\right)_{2}\right\}(\text { pyridine })_{2}(\mathrm{OH})_{2}\right]$, and $\left[\mathrm{Pt}\left\{\left(\left(\mathrm{p}-\mathrm{HC}_{6} \mathrm{~F}_{4}\right) \mathrm{NCH}_{2}\right)_{2}\right\}(\text { pyridine })_{2}(\mathrm{OH}) \mathrm{Cl}\right]$, J. Inorg. Biochem. 115 (2012) $226-239$.

[20] L.T.Ellis, H.M.Er, T.W. Hambley. The Influence of the Axial Ligands of a Series of Platinum(iv) Anti-Cancer Complexes on their Reduction to Platinum(ii) and Reaction with DNA, Aust. J. Chem., 48 (1995) 793-806.

[21] S. Choi, C. Filotto, M. Bisanzo, S. Delaney, D. Lagasee, J.L. Whitworth, A. Jusko, C. Li, N.A. Wood, J. Willingham, A. Schwenker, K. Spaulding, Reduction and Anticancer Activity of Platinum(IV) Complexes, Inorg. Chem. 37 (1998) 25002504

[22] J. Z. Zhang, E. Wexselblatt, T.W. Hambley, D. Gibson, Pt(IV) analogs of oxaliplatin that do not follow the expected correlation between electrochemical reduction potential and rate of reduction by ascorbate, Chem. Commun. 48 (2012) $847-849$ 
[23] H.P. Varbanov, S.M. Valiahdi, C.R. Kowol, M.A. Jakupec, M. Galanski, B.K. Keppler, Novel tetracarboxylatoplatinum(IV) complexes as carboplatin prodrugs, Dalton Trans. 41 (2012) 14213-1440

[24] M.D. Hall, H.R. Mellor, R. Callaghan, T.W. Hambley, Basis for design and development of platinum(IV) anticancer complexes, J. Med. Chem. 50 (2007) $3403-3411$.

[25] P. Zhang, P.J. Sadler, Redox-Active Metal Complexes for Anticancer Therapy, Eur. J. Inorg. Chem. (2017) 1541-1548.

[26] J.J. Wilson, S.J. Lippard, Synthetic methods for the preparation of platinum anticancer complexes, Chem. Rev. 114 (2014) 4470-4495.

[27] J.Z. Zhang, P. Bonnitcha, E. Wexselblatt, A.V. Klein, Y. Najajreh, D. Gibson, T.W. Hambley, Facile preparation of mono-, di- and mixed-carboxylato platinum(IV) complexes for versatile anticancer prodrug design, Chem. - A Eur. J. 19 (2013) 1672-1676.

[28] V. Pichler, S. Göschl, S.M. Meier, A. Roller, M.A. Jakupec, M. Galanski, B.K. Keppler, Bulky (N,N)-(Di)alkylethane-1,2-diamineplatinum(II) compounds as precursors for generating unsymmetrically substituted platinum(IV) complexes, Inorg. Chem. 52 (2013) 8151-8162.

[29] V. Pichler, P. Heffeter, S.M. Valiahdi, C.R. Kowol, A. Egger, W. Berger, M.A. Jakupec, M. Galanski, B.K. Keppler, Unsymmetric mono- and dinuclear 
platinum(IV) complexes featuring an ethylene glycol moiety: Synthesis, characterization, and biological activity, J. Med. Chem. 55 (2012) 11052-11061.

[30] S.Q. Yap, C.F. Chin, A.H. Hong Thng, Y.Y. Pang, H.K. Ho, W.H. Ang, Finely tuned asymmetric platinum(IV) anticancer complexes: Structure-activity relationship and application as orally available prodrugs, ChemMedChem. 12 (2017) 300-311.

[31] T.C. Johnstone, S.M. Alexander, J.J. Wilson, S.J. Lippard, Oxidative halogenation of cisplatin and carboplatin: synthesis, spectroscopy, and crystal and molecular structures of Pt(IV) prodrugs, Dalton Trans. 44 (2015) 119-29.

[32] Z. Xu, Z. Wang, S.-M. Yiu, G. Zhu, Mono- and di-bromo platinum(IV) prodrugs via oxidative bromination: synthesis, characterization, and cytotoxicity, Dalton Trans. 44 (2015) 19918-19926.

[33] Z. Xu, C. Li, Z. Tong, L. Ma, M. Tse, G. Zhu, Halogenated Pt ${ }^{\mathrm{IV}}$ complexes from N-Halosuccinimide oxidation of $\mathrm{Pt}^{\mathrm{II}}$ antitumor drugs: Synthesis, mechanistic investigation, and cytotoxicity, Eur. J. Inorg. Chem. (2016) 1-8.

[34] N. Graf, S.J. Lippard, Redox activation of metal-based prodrugs as a strategy for drug delivery, Adv. Drug Deliv. Rev. 64 (2012) 993-1004.

[35] E. Wexselblatt, E. Yavin, D. Gibson, Platinum(IV) prodrugs with haloacetato ligands in the axial positions can undergo hydrolysis under biologically relevant conditions, Angew. Chemie - Int. Ed. 52 (2013) 6059-6062. 
[36] M. Sinisi, F.P. Intini, G. Natile, Dependence of the reduction products of platinum(IV) prodrugs upon the configuration of the substrate, bulk of the carrier ligands, and nature of the reducing agent, Inorg. Chem. 51 (2012) 9694-9704.

[37] P. Zhang, P.J. Sadler, Advances in the design of organometallic anticancer complexes, J. Organomet. Chem. 839 (2017) 5-14.

[38] G. Gasser, I. Ott, N. Metzler-Nolte, Organometallic anticancer compounds, J. Med. Chem. 54 (2011) 3-25.

[39] A.L. Noffke, A. Habtemariam, A.M. Pizarro, P.J. Sadler, Designing organometallic compounds for catalysis and therapy, Chem. Comm, (2012) 52195246.

[40] C.G. Hartinger, N. Metzler-Nolte, P.J. Dyson, Challenges and opportunities in the development of organometallic anticancer drugs, Organometallics 31 (2012) $5677-5685$.

[41] I. Omae, Applications of five-membered ring products of cyclometalation reactions as anticancer agents, Coord. Chem. Rev. 280 (2014) 84-95.

[42] N. Cutillas, G.S. Yellol, C. De Haro, C. Vicente, V. Rodríguez, J. Ruiz, Anticancer cyclometalated complexes of platinum group metals and gold, Coord. Chem. Rev. 257 (2013) 2784-2797.

[43] I. Omae, Applications of cyclometalation reaction five-membered ring products, J. Organomet. Chem. 869 (2018) 88-105. 
[44] C. Navarro-Ranninger, I. López-Solera, V.M. González, J.M. Pérez, A. AlvarezValdés, A. Martín, P.R. Raithby, J.R. Masaguer, C. Alonso, Cyclometalated complexes of platinum and palladium with N-(4-Chlorophenyl)- $\alpha-$ benzoylbenzylideneamine. in vitro cytostatic activity, DNA modification, and interstrand cross-link studies, Inorg. Chem. 35 (1996) 5181-5187.

[45] I.M. El-Mehasseb, M. Kodaka, T. Okada, T. Tomohiro, K. Okamoto, H. Okuno, Platinum(II) complex with cyclometallating 2-Phenylpyridine ligand showing high cytoxicity against cisplatin-resistant cell, J. Inorg. Biochem. 84 (2001) 157-158.

[46] T. Okada, I.M. El-Mehasseb, M. Kodaka, T. Tomohiro, K. Okamoto, H. Okuno, Mononuclear platinum(II) complex with 2-phenylpyridine ligands showing high cytotoxicity against mouse sarcoma 180 cells acquiring high cisplatin resistance, J. Med. Chem. 44 (2001) 4661-4667.

[47] G.L. Edwards, D.S. Black, G.B. Deacon, L.P. Wakelin, In vitro and in vivo studies of neutral cyclometallated complexes against murine leukæmias, Can. J. Chem. 83 (2005) 980-989.

[48] G.L. Edwards, D.S. Black, G.B. Deacon, L.P. Wakelin, Effect of charge and surface area on the cytotoxicity of cationic metallointercalation reagents, Can. J. Chem. 83 (2005) 969-979.

[49] J. Ruiz, J. Lorenzo, C. Vicente, G. López, J.M. López-de-Luzuriaga, M. Monge, F.X. Avilés, D. Bautista, V. Moreno, A. Laguna, New palladium(II) and platinum(II) complexes with 9-aminoacridine: Structures, luminiscence, 
theoretical calculations, and antitumor activity, Inorg. Chem. 47 (2008) 69907001.

[50] J. Ruiz, V. Rodriguez, N. Cutillas, G. Lopez, D. Bautista, Acetonimine and 4imino-2-methylpentan-2-amino platinum(II) complexes: synthesis and in vitro antitumor activity, Inorg. Chem. 47 (2008) 10025-10036.

[51] J. Ruiz, J. Lorenzo, L. Sanglas, N. Cutillas, C. Vicente, M.D. Villa, F.X. Avilés, G. López, V. Moreno, J. Pérez, D. Bautista, Palladium(II) and platinum(II) organometallic complexes with the model nucleobase anions of thymine, uracil, and cytosine: Antitumor activity and interactions with DNA of the platinum compounds, Inorg. Chem. 45 (2006) 6347-6360.

[52] H. Samouei, M. Rashidi, F.W. Heinemann, A cyclometalated diplatinum complex containing 1,1'-bis(diphenylphosphino)ferrocene as spacer ligand: Antitumor study, J. Organomet. Chem. 696 (2011) 3764-3771.

[53] D. Talancón, C. López, M. Font-Bardía, T. Calvet, J. Quirante, C. Calvis, R. Messeguer, R. Cortés, M. Cascante, L. Baldomà, J. Badia, Diastereomerically pure platinum(II) complexes as antitumoral agents.: The influence of the mode of binding $\left\{(\mathrm{N}), \quad(\mathrm{N}, \mathrm{O})^{-} \quad \text { or } \quad(\mathrm{C}, \mathrm{N})\right\}^{-} \quad$ of $\quad(1 \mathrm{~S}, 2 \mathrm{R})\left[\left(\eta^{5}-\mathrm{C}_{5} \mathrm{H}_{5}\right) \mathrm{Fe}\left\{\left(\eta^{5}-\right.\right.\right.$ $\left.\left.\left.\mathrm{C}_{5} \mathrm{H}_{4}\right) \mathrm{CHNCH}(\mathrm{Me}) \mathrm{CH}(\mathrm{OH}) \mathrm{C}_{6} \mathrm{H}_{5}\right\}\right]$ and the arrangement of the auxiliary ligands, J. Inorg. Biochem. 118 (2013) 1-12.

[54] J. Albert, R. Bosque, M. Crespo, J. Granell, C. López, R. Cortés, A. Gonzalez, J. Quirante, C. Calvis, R. Messeguer, L. Baldomà, J. Badia, M. Cascante, Pt(II) 
complexes with $\left(\mathrm{N}, \mathrm{N}^{\prime}\right)$ or $(\mathrm{C}, \mathrm{N}, \mathrm{E})-(\mathrm{E}=\mathrm{N}, \mathrm{S})$ ligands: Cytotoxic studies, effect on DNA tertiary structure and structure-activity relationships, Bioorg. Med. Chem. 21 (2013) 4210-4217.

[55] J. Ruiz, C. Vicente, C. De Haro, A. Espinosa, Synthesis and antiproliferative activity of a $\mathrm{C} / \mathrm{N}$-cycloplatinated(II) complex with a potentially intercalative anthraquinone pendant, Inorg. Chem. 50 (2011) 2151-2158.

[56] N. Cutillas, A. Martínez, G.S. Yellol, V. Rodríguez, A. Zamora, M. Pedreño, A. Donaire, C. Janiak, J. Ruiz, Anticancer C,N-cycloplatinated(II) complexes containing fluorinated phosphine ligands: Synthesis, structural characterization, and biological activity, Inorg. Chem. 52 (2013) 13529-13535.

[57] R. Cortés, M. Crespo, L. Davin, R. Martín, J. Quirante, D. Ruiz, R. Messeguer, C. Calvis, L. Baldomà, J. Badia, M. Font-Bardía, T. Calvet, M. Cascante, Sevenmembered cycloplatinated complexes as a new family of anticancer agents. X-ray characterization and preliminary biological studies, Eur. J. Med. Chem. 54 (2012) $557-566$.

[58] D.L. Ma, C.M. Che, A bifunctional platinum(II) complex capable of intercalation and hydrogen-bonding interactions with DNA: Binding studies and cytotoxicity, Chem. - A Eur. J. 9 (2003) 6133-6144.

[59] P. Wang, C.H. Leung, D.L. Ma, R.W.Y. Sun, S.C. Yan, Q.S. Chen, C.M. Che, Specific blocking of CREB/DNA binding by cyclometalated platinum(II) complexes, Angew. Chemie - Int. Ed. 50 (2011) 2554-2558. 
[60] J. Quirante, D. Ruiz, A. Gonzalez, C. López, M. Cascante, R. Cortés, R. Messeguer, C. Calvis, L. Baldomà, A. Pascual, Y. Guérardel, B. Pradines, M. FontBardía, T. Calvet, C. Biot, Platinum(II) and palladium(II) complexes with (N,N') and $\left(\mathrm{C}, \mathrm{N}, \mathrm{N}^{\prime}\right)$ - ligands derived from pyrazole as anticancer and antimalarial agents: Synthesis, characterization and in vitro activities, J. Inorg. Biochem. 105 (2011) $1720-1728$.

[61] P. Chellan, K.M. Land, A. Shokar, A. Au, S.H. An, C.M. Clavel, P.J. Dyson, C. De Kock, P.J. Smith, K. Chibale, G.S. Smith, Exploring the versatility of cycloplatinated thiosemicarbazones as antitumor and antiparasitic agents, Organometallics 31 (2012) 5791-5799.

[62] D.A.K. Vezzu, Q. Lu, Y.H. Chen, S. Huo, Cytotoxicity of cyclometalated platinum complexes based on tridentate NCN and CNN-coordinating ligands: Remarkable coordination dependence, J. Inorg. Biochem. 134 (2014) 49-56.

[63] M. Jamshidi, R. Yousefi, S.M. Nabavizadeh, M. Rashidi, M.G. Haghighi, A. Niazi, A.-A. Moosavi-Movahedi, Anticancer activity and DNA-binding properties of novel cationic Pt(II) complexes, Int. J. Biol. Macromol. 66 (2014) 86-96.

[64] J. Albert, R. Bosque, M. Crespo, J. Granell, C. López, R. Martín, A. González, A. Jayaraman, J. Quirante, C. Calvis, J. Badía, L. Baldomà, M. Font-Bardia, M. Cascante, R. Messeguer, Neutral and ionic platinum compounds containing a cyclometallated chiral primary amine: synthesis, antitumor activity, DNA interaction and topoisomerase I-cathepsin B inhibition, Dalton Trans. 44 (2015) $13602-14$. 
[65] M. Clemente, I.H. Polat, J. Albert, R. Bosque, M. Crespo, J. Granell, C. López, M. Martínez, J. Quirante, R. Messeguer, C. Calvis, J. Badia, L. Baldomà, M. FontBardia, M. Cascante, Platinacycles containing a primary amine platinum(II) compounds for treating cisplatin-resistant cancers by oxidant therapy, Organometallics (2018) doi:10.1021/acs.organomet.8b00206.

[66] M. V. Babak, M. Pfaffeneder-Kmen, S.M. Meier-Menches, M.S. Legina, S. Theiner, C. Licona, C. Orvain, M. Hejl, M. Hanif, M.A. Jakupec, B.K. Keppler, C. Gaiddon, C.G. Hartinger, Rollover cyclometalated bipyridine platinum complexes as potent anticancer agents: Impact of the ancillary ligands on the mode of action, Inorg. Chem. 57 (2018) 2851-2864.

[67] J. Albert, L. D'Andrea, J. Granell, P. Pla-Vilanova, J. Quirante, M. K. Khosa, C, Calvis, R. Messeguer, J. Badia, L. Baldomà, M. Font-Bardia,T. Calvet, Cyclopalladated and cycloplatinated benzophenone imines: Antitumor, antibacterial and antioxidant activities, DNA interaction and cathepsin B inhibition, J. Inorg. Biochem. 140 (2014) 80-88.

[68] U. Frey, L. Helm, A.E. Merbach, R. Romeo, Dissociative substitution in fourcoordinate planar platinum(II) complexes as evidenced by variable-pressure highresolution proton NMR magnetization transfer experiments, J. Am. Chem. Soc. $111(1989) 8161-8165$.

[69] M.R. Plutino, L.M. Scolaro, R. Romeo, A. Grassi, To what extent can cyclometalation promote associative or dissociative ligand substitution at 
platinum(II) complexes? A combined kinetic and theoretical approach, Inorg. Chem. 39 (2000) 2712-2720.

[70] Y. Zhang, Q. Luo, W. Zheng, Z. Wang, Y. Lin, E. Zhang, S. Lü, J. Xiang, Y. Zhao, F. Wang, Luminescent cyclometallated platinum(II) complexes: highly promising EGFR/DNA probes and dual-targeting anticancer agents, Inorg. Chem. Front. 5 (2018) 413-424.

[71] J.R. Berenguer, J.G. Pichel, N. Giménez, E. Lalinde, M.T. Moreno, S. PineiroHermida, Luminescent pentafluorophenyl-cycloplatinated complexes: synthesis, characterization, photophysics, cytotoxicity and cellular imaging, Dalton Trans. 44 (2015) 18839-18855.

[72] M. Mauro, A. Aliprandi, D. Septiadi, N.S. Kehr, L. De Cola, When self-assembly meets biology: luminescent platinum complexes for imaging applications, Chem. Soc. Rev. 43 (2014) 4144-4166.

[73] J.L.-L. Tsai, T. Zou, J. Liu, T. Chen, A.O.-Y. Chan, C. Yang, C.-N. Lok, C.-M. Che, Luminescent platinum(II) complexes with self-assembly and anti-cancer properties: hydrogel, $\mathrm{pH}$ dependent emission color and sustained-release properties under physiological conditions, Chem. Sci. 6 (2015) 3823-3830.

[74] A. Lüning, J. Schur, L. Hamel, I. Ott, A. Klein, Strong cytotoxicity of organometallic platinum complexes with alkynyl ligands, Organometallics 32 (2013) 3662-3672.

[75] A. Klein, A. Lüning, I. Ott, L. Hamel, M. Neugebauer, K. Butsch, V. Lingen, F. 
Heinrich, S. Elmas, Organometallic palladium and platinum complexes with strongly donating alkyl coligands - Synthesis, structures, chemical and cytotoxic properties, J. Organomet. Chem. 695 (2010) 1898-1905.

[76] K. Butsch, S. Elinas, N.S. Gupta, R. Gust, F. Heinrich, A. Klein, Y. Von Mering, M. Neugebauer, I. Ott, M. Schäfer, H. Scherer, T. Schurr, Organoplatinum(II) and -palladium(II) complexes of nucleobases and their derivatives, Organometallics 28 (2009) 3906-3915.

[77] M. Enders, B. Görling, A.B. Braun, J.E. Seltenreich, L.F. Reichenbach, K. Rissanen, M. Nieger, B. Luy, U. Schepers, S. Bräse, Cytotoxicity and NMR studies of platinum complexes with cyclooctadiene ligands, Organometallics 33 (2014) 4027-4034.

[78] A. Lüning, M. Neugebauer, V. Lingen, A. Krest, K. Stirnat, G.B. Deacon, P.R. Drago, I. Ott, J. Schur, I. Pantenburg, G. Meyer, A. Klein, Platinum diolefin complexes - Synthesis, structures, and cytotoxicity, Eur. J. Inorg. Chem. (2015) $226-239$.

[79] C. Cullinane, G.B. Deacon, P.R. Drago, T.W. Hambley, K.T. Nelson, L.K. Webster, Preparation and cell growth inhibitory activity of $\left[\mathrm{PtR}_{2} \mathrm{~L}_{2}\right]$ ( $\mathrm{R}=$ polyfluorophenyl, $\mathrm{L}_{2}=$ diene, cyclohexane-1,2-diamine (chxn) or cis-(dimethyl sulfoxide) $)$ and the X-ray crystal structure of $\left[\mathrm{Pt}\left(\mathrm{C}_{6} \mathrm{~F}_{5}\right)(\right.$ cis-chxn)], J. Inorg. Biochem. 89 (2002) 293-301.

[80] J. Ruiz, V. Rodríguez, C. de Haro, A. Espinosa, J. Pérez, C. Janiak, New 7- 
azaindole palladium and platinum complexes: crystal structures and theoretical calculations. In vitro anticancer activity of the platinum compounds., Dalton Trans. 39 (2010) 3290-3301.

[81] C. Cullinane, G.B. Deacon, P.R. Drago, A.P. Erven, P.C. Junk, J. Luu, G. Meyer, S. Schmitz, I. Ott, J. Schur, L.K. Webster, A. Klein, Synthesis and antiproliferative activity of a series of new platinum and palladium diphosphane complexes, Dalton Trans. 47 (2018) 1918-1932.

[82] M. Gay, Á.M. Montaña, V. Moreno, M.J. Prieto, R. Llorens, L. Ferrer, Studies of interaction of dichloro[ $\eta^{2}$-dimethyl-(2-methylidene-cyclohexylmethyl)amino]platinum(II) with DNA: Effects on secondary and tertiary structures of DNA - Cytotoxic assays on human cancer cell lines Capan 1 and A431, J. Inorg. Biochem. 99 (2005) 2387-2394.

[83] S. Jean, K. Cormier, A.E. Patterson, C.M. Vogels, A. Decken, G.A. Robichaud, S. Turcotte, S.A. Westcott, Synthesis, characterization, and anticancer properties of organometallic Schiff base platinum complexes, Can. J. Chem. 93 (2015) 11401146

[84] M.E. Cucciolito, A. D’Amora, G. De Feo, G. Ferraro, A. Giorgio, G. Petruk, D.M. Monti, A. Merlino, F. Ruffo, Five-Coordinate Platinum(II) compounds containing sugar ligands: Synthesis, characterization, cytotoxic activity, and interaction with biological macromolecules, Inorg. Chem. 57 (2018) 3133-3143.

[85] T.W. Hambley, A.R. Battle, G.B. Deacon, E.T. Lawrenz, G.D. Fallon, B.M. 
Gatehouse, L.K. Webster, S. Rainone, Modifying the properties of platinum(IV) complexes in order to increase biological effectiveness, J. Inorg. Biochem. 77 (1999) 3-12.

[86] Z. Pouryasin, R. Yousefi, S.M. Nabavizadeh, M. Rashidi, P. Hamidizadeh, M.-M. Alavianmehr, A.A. Moosavi-Movahedi, Anticancer and DNA binding activities of platinum (IV) complexes; Importance of leaving group departure rate, Appl. Biochem. Biotechnol. 172 (2014) 2604-2617.

[87] E. Bauer, X. Domingo, C. Balcells, I.H. Polat, M. Crespo, J. Quirante, J. Badía, L. Baldomà, M. Font-Bardia, M. Cascante, Synthesis, characterization and biological activity of new cyclometallated platinum(IV) iodido complexes, Dalton Trans. 46 (2017) 14973-14987.

[88] A. Escolà, M. Crespo, J. Quirante, R. Cortés, A. Jayaraman, J. Badia, L. Baldomà, T. Calvet, M. Font-Bardia, M. Cascante, Exploring the scope of $\left[\mathrm{Pt}_{2}\left(4-\mathrm{FC} \mathrm{H}_{4}\right)_{4}(\mu-\right.$ $\left.\left.\mathrm{SEt}_{2}\right)_{2}\right]$ as a precursor for new organometallic platinum(II) and platinum(IV) antitumor agents, Organometallics 33 (2014) 1740-1750.

[89] A. Escolà, M. Crespo, C. López, J. Quirante, A. Jayaraman, I.H. Polat, J. Badía, L. Baldomà, M. Cascante, On the stability and biological behavior of cyclometallated Pt(IV) complexes with halido and aryl ligands in the axial positions, Bioorg. Med. Chem. 24 (2016) 5804-5815.

[90] M. Solé, C. Balcells, M. Crespo, J. Quirante, J. Badia, L. Baldomà, M. FontBardia, M. Cascante, Synthesis, characterization and biological activity of new 
cyclometallated platinum(IV) complexes containing a para-tolyl ligand, Dalton Trans. 47 (2018) 8956-8971.

[91] C.M. Anderson, R.J. Puddephatt, G. Ferguson, A.J. Lough, Oxidative addition of aryl-halogen bonds to platinum(II) and the structure of a complex formed by arylfluoride oxidative addition, J. Chem. Soc. Chem. Commun. 18 (1989) 1297-1298.

[92] C.M. Anderson, M. Crespo, M.C. Jennings, A.J. Lough, G. Ferguson, R.J. Puddephatt, Competition between intramolecular oxidative addition and ortho metalation in organoplatinum(II) compounds: activation of aryl-halogen bonds, Organometallics 10 (1991) 2672-2679.

[93] C.M. Anderson, M. Crespo, G. Ferguson, A.J. Lough, R.J. Puddephatt, Activation of aromatic carbon-fluorine bonds by organoplatinum complexes, Organometallics 11 (1992) 1177-1181.

[94] O. Lopez, M. Crespo, M. Font-Bardia, X. Solans, Activation of C-F and C-H bonds by platinum in trifluorinated [ C, N, N ' ] ligands. Organometallics 16 (1997) 12331240.

[95] A. Capapé, M. Crespo, J. Granell, M. Font-Bardía, X. Solans, Synthesis and reactivity of cyclometallated platinum (II) compounds containing [C,N,N'] terdentate ligands: Crystal structures of $\left[\mathrm{PtCl}\left\{\left(\mathrm{CH}_{3}\right)_{2} \mathrm{~N}\left(\mathrm{CH}_{2}\right)_{3} \mathrm{NCH}\left(4-\mathrm{ClC}_{6} \mathrm{H}_{3}\right)\right\}\right]$, $\left[\operatorname{PtCl}\left\{\left(\mathrm{CH}_{3}\right)_{2} \mathrm{~N}\left(\mathrm{CH}_{2}\right)_{3} \mathrm{NCH}\left(2-\mathrm{ClC}_{6} \mathrm{H}_{3}\right)\right\}\right]$, J. Organomet. Chem. 690 (2005) 43094318.

[96] A. Gandioso, J. Valle-Sistac, L. Rodríguez, M. Crespo, M. Font-Bardía, 
Platinum(II) compounds containing cyclometalated tridentate ligands: Synthesis, luminescence studies, and a selective fluoro for methoxy substitution, Organometallics 33 (2014) 561-570.

[97] M. Crespo, M. Martinez, J. Sales, X. Solans, M. Font-Bardia, Syntheses and mechanistic studies in the formation of endo- and exo-cyclometalated platinum compounds of N-benzylidenebenzylamines, Organometallics 11 (1992) 12881295.

[98] M. Crespo, M. Martinez, J. Sales, Effect of Fluorine Substituents in Intramolecular Activation of C-F and C-H Bonds by Platinum(II), Organometallics 12 (1993) $4297-4304$.

[99] M. Crespo, M. Font-Bardia, X. Solans, Compound [ $\left.\mathrm{PtPh}_{2}\left(\mathrm{SMe}_{2}\right)_{2}\right]$ as a versatile metalating agent in the preparation of new types of $\left[\mathrm{C}, \mathrm{N}, \mathrm{N}^{\prime}\right]$ cyclometalated platinum compounds, Organometallics 23 (2004) 1708-1713.

[100] R. Martin, M. Crespo, M. Font-Bardia, T. Calvet, Five- and seven-membered metallacycles in $\left[\mathrm{C}, \mathrm{N}, \mathrm{N}^{\prime}\right]$ and $[\mathrm{C}, \mathrm{N}]$ Cycloplatinated Compounds, Organometallics 28 (2009) 587-597.

[101] T. Calvet, M. Crespo, M. Font-Bardía, S. Jansat, M. Martínez, Kineticomechanistic studies on intramolecular $\mathrm{C}-\mathrm{X}$ bond activation $(\mathrm{X}=\mathrm{Br}, \mathrm{Cl})$ of aminoimino ligands on $\mathrm{Pt}(\mathrm{II})$ compounds. Prevalence of a concerted mechanism in nonpolar, polar, and ionic liquid media, Organometallics 31 (2012) 4367-4373.

[102] L. Rendina, R. Puddephatt, Oxidative Addition Reactions of Organoplatinum (II) 
Complexes with Nitrogen-Donor Ligands, Chem. Rev. 97 (1997) 1735-1754.

[103] J.A. Labinger, Tutorial on Oxidative Addition, Organometallics 34 (2015) 47844795.

[104] M. Ghedini, D. Pucci, A. Crispini, G. Barberio, Oxidative Addition to Cyclometalated Azobenzene Platinum(II) Complexes: A Route to Octahedral Liquid Crystalline Materials, Organometallics 18 (1999) 2116-2124.

[105] C. Anderson, M. Crespo, M. Font-Bardia, X. Solans, Oxidative addition of alkyl halides to chiral cyclometallated platinum (II) complexes with thienyl imines. Xray crystal structure of [ PtMe $\left.\left\{3-((\mathrm{S})-\mathrm{PhCHMeNCH}) \mathrm{C}_{4} \mathrm{H}_{2} \mathrm{~S}\right\} \mathrm{SMe}_{2}\right], \quad \mathrm{J}$. Organomet. Chem. 604 (2000) 178-185.

[106] C. Anderson, M. Crespo, F.D. Rochon, Stereoselective oxidative addition of methyl iodide to chiral cyclometallated platinum(II) compounds derived from (R)(+)-1-(1-naphthylethylamine). Crystal structure of $\quad[\operatorname{PtMe}\{3-(\mathrm{R})-$ $\left.\left.\left(\mathrm{C}_{10} \mathrm{H}_{7}\right) \mathrm{CHMeNCHC}{ }_{4} \mathrm{H}_{2} \mathrm{~S}\right\} \mathrm{PPh}_{3}\right]$, J. Organomet. Chem. 631 (2001) 164-174.

[107] J. Mamtora, S.H. Crosby, C.P. Newman, G.J. Clarkson, J.P. Rourke, Platinum (IV) Complexes: C-H Activation at Low Temperatures, Organometallics 27 (2008) $5559-5565$.

[108] L. Maidich, A. Zucca, G.J. Clarkson, J.P. Rourke, Oxidative addition of MeI to a rollover complex of platinum(II): Isolation of the kinetic product, Organometallics 32 (2013) 3371-3375. 
[109] P.A. Shaw, G.J. Clarkson, J.P. Rourke, Reversible C-C bond formation at a triply cyclometallated platinum(IV) centre, Chem. Sci. 8 (2017) 5547-5558.

[110] P.V. Bernhardt, T. Calvet, M. Crespo, M. Font-Bardia, S. Jansat, M. Martinez, New insights in the formation of five- versus seven-membered platinacycles: a kinetico-mechanistic study, Inorg. Chem. 52 (2013) 474-484.

[111] P. V. Bernhardt, C. Gallego, M. Martinez, Mechanisms of substitution reactions on cyclometallated platinum(IV) complexes: "Quasi-labile" systems, Organometallics. 19 (2000) 4862-4869.

[112] M. Crespo, M. Font-Bardia, P. Hamidizadeh, M. Martinez, M. Nabavizadeh, Kinetico-mechanistic study on the reduction/complexation sequence of PtIV/PtII organometallic complexes by some thiol-containing biological molecules, (2018) manuscript in preparation.

[113] V. Pichler, S. Göschl, E. Schreiber-Brynzak, M.A. Jakupec, M. Galanski, B.K. Keppler, Influence of reducing agents on the cytotoxic activity of platinum(IV ) complexes: induction of G2/M arrest, apoptosis and oxidative stress in A2780 and cisplatin resistant A2780cis cell lines, Metallomics. 7 (2015) 1078-1090.

[114] S. Göschl, P.V. Hristo, S. Theiner, M.A. Jakupec, M. Galanski, B.K. Keppler, The role of the equatorial ligands for the redox behavior, cellular accumulation and cytotoxicity of platinum(IV) prodrugs. New insights into their cellular accumulation mechanisms, J. Inorg. Biochem. 160 (2016) 264-274. 